\title{
Biofertilizer-Based Zinc Application Enhances Maize Growth, Gas Exchange Attributes, and Yield in Zinc-Deficient Soil
}

\author{
Abdul Saboor ${ }^{1}$, Muhammad Arif Ali ${ }^{1, *(D)}$, Niaz Ahmed ${ }^{1}$, Milan Skalicky ${ }^{2} \mathbb{D}$, Subhan Danish ${ }^{1}\left(\mathbb{D}\right.$, Shah Fahad $^{3,4}$, \\ Fahmy Hassan ${ }^{5} \mathbb{D}$, Mohamed M. Hassan ${ }^{5}\left(\mathbb{D}\right.$, Marian Brestic ${ }^{2,6}{ }^{\mathbb{D}}$, Ayman EL Sabagh ${ }^{7}$ and Rahul Datta ${ }^{8, *}$
}

1 Department of Soil Science, Faculty of Agricultural Sciences and Technology, Bahauddin Zakariya University, Multan 60800, Pakistan; abdulsabooruaf36d@gmail.com (A.S.); niaz.ahmad@bzu.edu.pk (N.A.); sd96850@gmail.com (S.D.)

2 Department of Botany and Plant Physiology, Faculty of Agrobiology, Food and Natural Resources, Czech University of Life Sciences Prague, Kamycka 129, 16500 Prague, Czech Republic; skalicky@af.czu.cz (M.S.); marian.brestic@uniag.sk (M.B.)

3 Hainan Key Laboratory for Sustainable Utilization of Tropical Bioresource, College of Tropical Crops, Hainan University, Haikou 570228, China; shah_fahad80@yahoo.com

4 Department of Agronomy, The University of Haripur, Haripur 22620, Pakistan

5 Department of Biology, College of Science, Taif University, P.O. Box 11099, Taif 21944, Saudi Arabia; d.fahmy@tu.edu.sa (F.H.); m.khyate@tu.edu.sa (M.M.H.)

6 Department of Plant Physiology, Slovak University of Agriculture, Nitra, Tr. A. Hlinku 2, 94901 Nitra, Slovakia

Citation: Saboor, A.; Ali, M.A.; Ahmed, N.; Skalicky, M.; Danish, S.; Fahad, S.; Hassan, F.; Hassan, M.M.; Brestic, M.; EL Sabagh, A.; et al. Biofertilizer-Based Zinc Application Enhances Maize Growth, Gas Exchange Attributes, and Yield in Zinc-Deficient Soil. Agriculture 2021, 11,310. https://doi.org/10.3390/ agriculture11040310

Academic Editors: Laura Ercoli and Eric Blanchart

Received: 20 February 2021

Accepted: 29 March 2021

Published: 2 April 2021

Publisher's Note: MDPI stays neutral with regard to jurisdictional claims in published maps and institutional affiliations.

Copyright: (c) 2021 by the authors. Licensee MDPI, Basel, Switzerland. This article is an open access article distributed under the terms and conditions of the Creative Commons Attribution (CC BY) license (https:// creativecommons.org/licenses/by/ $4.0 /)$.
7 Department of Agronomy, Faculty of Agriculture, Kafrelsheikh University, Kafrelsheikh 33516, Egypt; ayman.elsabagh@agr.kfs.edu.eg

8 Department of Geology and Pedology, Faculty of Forestry and Wood Technology, Mendel University in Brno, Zemedelska 1, 61300 Brno, Czech Republic

* Correspondence: arif1056@bzu.edu.pk (M.A.A.); rahulmedcure@gmail.com (R.D.)

Abstract: Zinc (Zn) concentration in soil varies from deficient to toxic. Its deficiency, as well as toxicity, through imbalanced application and cropping in industrial sites can reduce maize growth and yield. Therefore, balanced $\mathrm{Zn}$ application is necessary to save resources and achieve optimum growth and yield in maize. Arbuscular mycorrhizal fungi (AMF) can provide tolerance to the host plant against $\mathrm{Zn}$-induced stress. Inoculation with AMF helps in regulating the uptake of $\mathrm{Zn}$ and enhances the growth and yield of crops. Different application rates of Zn (0, 20, 40, 60, 80, 100, and $120 \mathrm{mg} \mathrm{Zn} \mathrm{kg}^{-1}$ ) were applied with inoculation with AMF (AM) and without AMF (NM). Results showed that root colonization was 45\% higher in AMF-inoculated plants than noninoculated plants. A significant increase in plant height (15\%), number of leaves $(35.4 \%)$, cob weight (4.39\%), 1000-grain weight (10.5\%), and biological yield (42.2\%) signified the efficacious functioning of Zn20 + AM over sole inoculation with AM. We also observed that AMF inoculation with Zn20 helped to improve photosynthesis, transpiration, and stomatal conductance. Furthermore, both $\mathrm{Zn} 20+\mathrm{AM}$ and Zn20 + AM significantly increased total soluble protein compared with AM. Higher application rates of zinc, i.e., Zn80 and Zn120, induced Zn toxicity with (AM) and without (NM) AMF. In conclusion, $\mathrm{Zn} 20+\mathrm{AM}$ is an effective treatment to achieve better growth and maize yield without $\mathrm{Zn}$ deficiency or toxicity.

Keywords: arbuscular mycorrhizal fungi; maize; zinc; gas exchange attributes; morphological attributes; yield

\section{Introduction}

Maize (Zea mays L.) is the third most cultivated crop and a member of the Poaceae (Gramineae) family. In Pakistan, it is normally cultivated in spring and autumn [1]. The Punjab and Khyber Pakhtunkhwa (KPK) provinces are major maize producers in Pakistan, accounting for about $97 \%$ of total production [2]. Maize is considered an exhaustive 
nutrient crop as its uptakes a high amount of nutrients from the soil. Unfortunately, soils in Pakistan cannot supply a sufficient quantity of nutrients [3-5], especially zinc (Zn), to fulfill plant demands and improve crop yield [6-8].

Zinc is considered the most important micronutrient for normal and healthy plant growth $[3,4,6,9]$. It is a structural component or cofactor of various enzymes involved in many biochemical processes. In plants, it is involved in photosynthesis, carbohydrate metabolism, protein metabolism, pollen formation, auxin metabolism, maintenance of membrane integrity, and induction of tolerance against various stresses [10]. The total concentration of $\mathrm{Zn}$ in soil ranges from 10 to $300 \mathrm{mg} \mathrm{Zn} \mathrm{kg}^{-1}$ soil, and the average is $55 \mathrm{mg} \mathrm{Zn} \mathrm{kg}{ }^{-1}$ soil. However, most $\mathrm{Zn}$ forms complexes with soil colloids and organic matter (OM), reducing $\mathrm{Zn}$ bioavailability for plants. Therefore, a very small amount of $\mathrm{Zn}$ is normally available for plant uptake.

Zinc deficiency in soil is a global problem. Arid and semi-arid soils are usually deficient in $\mathrm{Zn}$ due to the high immobilization of $\mathrm{Zn}$. Furthermore, high soil pH (8.0 to more than 8.5) drastically reduces soil Zn bioavailability. Soils in Pakistan mostly exhibit high soil $\mathrm{pH}$, high $\mathrm{CaCO}_{3}$, and low OM content; therefore, $\mathrm{Zn}$ deficiency is a major issue in most regions [11]. High input of phosphatic fertilizers also reduces $\mathrm{Zn}$ bioavailability due to the formation of insoluble $\mathrm{Zn}$ phosphates in soil. The soil microbial application technique is considered the best among the various available methods to achieve optimum plant growth and yield [6,8,12-21]. Commonly used organic amendments [22-24] and soil microbial techniques include the application of plant growth-promoting bacteria [25-28], Zn-solubilizing bacteria, and arbuscular mycorrhizal fungi. Arbuscular mycorrhizal fungi colonize the plant roots and form a symbiotic relationship with plants by providing nutrients, water, and protection from pathogens [29]. More than $90 \%$ of terrestrial plants benefit from this symbiosis [30]. Their contribution in increasing the uptake of nutrients $(\mathrm{P}, \mathrm{Zn}$, $\mathrm{Fe}, \mathrm{Cu}$, and $\mathrm{K}$ ) from the soil system to plants is well known [14]. Arbuscular mycorrhizal fungi (AMF) also mediates the toxic effects of metals $(\mathrm{Zn})$ and exerts a protective effect to promote plant growth under metal-polluted conditions [31]. It has been observed that AMF-inoculated plants produced more biomass as compared to non-inoculated plants. Increased biomass is directly related to improved plant nutrition due to increased root colonization rate [32].

AMF contribution to Zn uptake was quantified by Jansa et al. [33]. After that, WattsWilliams et al. [34] quantified the total Zn uptake and mycorrhizal contribution and plant dependency on Rhizophagus irregularis. In wheat and barley, R. irregularis contributed to up to $24.3 \%$ and $12.7 \%$ of $\mathrm{Zn}$ uptake, respectively [14]. Therefore, the current study was conducted to explore the potential benefits of AMF on maize growth and yield attributes under different $\mathrm{Zn}$ application rates. The study aimed to assess the performance of AMF under $\mathrm{Zn}$ deficiency and toxicity conditions. It was hypothesized that AMF can help in decreasing the application rate of $\mathrm{Zn}$. AMF can also play an important role in the improvement of growth, gas exchange attributes, and yield of maize

\section{Materials and Methods}

\subsection{Experimental Soil and Location}

A completely randomized design (CRD) pot experiment was conducted at the research area of the Department of Soil Science, Bahauddin Zakariya University, Multan, Pakistan. Extractable zinc was deficient $\left(0.52 \mathrm{mg} \mathrm{Zn} \mathrm{kg}^{-1}\right)$ in soil collected from the Chak 5 Faiz location (latitude $29.9^{\circ} \mathrm{N}$ and longitude $71.5^{\circ} \mathrm{E}$ ).

\subsection{Experimental Soil Characterization}

Air-dried samples of soil of 2-mm mesh size were mixed with sand in an 8:2 ratio, termed soil. After mixing, soil was analyzed for various physicochemical properties. It contained $39 \%$ saturation, $54 \%$ water-holding capacity, $0.14 \mathrm{dSm}^{-1} \mathrm{ECe}$ [35], $8.82 \mathrm{pH}$ [36], $6.5 \mathrm{mg} \mathrm{kg}^{-1}$ available P [37], $126 \mathrm{mg} \mathrm{kg}^{-1}$ extractable K [38], 0.43\% organic matter [39], and $0.0215 \%$ total $\mathrm{N}[40]$. 


\subsection{Pot Preparation by Addition of $\mathrm{Zn}$ and $A M F$}

Non-draining pots were filled with $20 \mathrm{~kg}$ soil inoculated with $5 \mathrm{~g}$ mycorrhizal inoculum Clonex ${ }^{\circledR}$ (Root Maximizer; 5711 Enterprise Drive, Lansing, MI, USA) having 158 propagule gram ${ }^{-1}$. Glomus species were the major constituents of the inoculum. In AMF-controlled pots $\left(\mathrm{M}^{-}\right)$, Topsin M (Thiophanate Methyl 70\% wettable powder (WP)) was applied at $50 \mathrm{mg} \mathrm{kg}^{-1}$ soil for reducing AMF root colonization. Six Zn doses (20, 40, $60,80,100$, and $120 \mathrm{mg} \mathrm{Zn} \mathrm{kg}^{-1}$ soil in $\mathrm{ZnSO}_{4}$ form) were applied along with a control treatment without $\mathrm{Zn}$ addition. The treatments are referred to as $\mathrm{Zn} 0, \mathrm{Zn} 20, \mathrm{Zn} 60$, Zn80, Zn100, and Zn120.

\subsection{Moisture Maintenance and Fertilizer Addition}

The moisture content in each pot was maintained at $60 \%$ of the total WHC on a weight basis [41], and the recommended doses of $\mathrm{N}$ and $\mathrm{K}$ with half $\mathrm{P}$ fertilizers were applied at the rate of $227.24: 71.63: 91.39 \mathrm{~kg} \mathrm{ha}^{-1}$.

\subsection{Seeds Sowing and Thinning}

Maize variety YH 1898 was used in this study. Two weeks after germination, plants were thinned to two plants per pot and were irrigated until maturity.

\subsection{Morphological Attributes}

At the time of maturity (R6 = milk line no longer evident, black layer formed; end of mass gain; maximum dry weight is attained), plants were harvested. Plant agronomic parameters such as the number of leaves were counted, and plant height $(\mathrm{cm})$ and stem girth $(\mathrm{cm})$ were measured using a measuring tape before harvesting in three replications.

\subsection{Yield Parameters}

At maturity (115 days after sowing), the aboveground biomass of plants in all pots was destructively sampled and the weights of grains and residues were determined. The number of leaves was counted manually and cob length was noted by using a standard measuring tape.

\subsection{Gas Exchange Attributes}

Stomatal conductance, photosynthetic rate, and transpiration rate were measured at the tasseling stage (V12-V14; 45 days after germination when leaves' growth was active) with constant light intensity of a photosynthesis device $\left(1500 \mu \mathrm{mol} \mathrm{m}^{-2} \mathrm{~s}^{-1}\right), \mathrm{CO}_{2}$ concentration $(400 \mu \mathrm{mol})$, and airflow $\left(500 \mu \mathrm{mol} \mathrm{s}^{-1}\right)$. When photosynthesis reached a steady state, the measurement was recorded by an LCi- SD Ultra Compact Photosynthesis System ${ }^{\circledR}$ between 10:30 and 11:30 a.m. at a saturating intensity of light $[16,42,43]$.

\subsection{Total Soluble Protein (TSP)}

Composite leaf samples (V12-V14; 45 days after germination when leaves' growth was active) were stored at $-80^{\circ} \mathrm{C}$ in a freezer (Panasonic Japan; MDF-U55V-PE). For enzyme extraction, samples were vortexed and then centrifuged in potassium phosphate buffer ( $\mathrm{pH} 4$ ). Bradford reagent was added, and absorbance was measured using an ELISA plate at a wavelength of $595 \mathrm{~nm}$ [44].

\subsection{AMF Colonization Determination/Measurement}

Roots were harvested for AMF root colonization assessment by the gridline intersect method [45]. Briefly, roots were washed in $10 \% \mathrm{KOH}$ solution, and trypan blue staining was used to observe arbuscular mycorrhizal colonization in root tissues by following the method developed by Phillips and Hayman [46]. 


\subsection{Statistical Analysis}

Data were statistically analyzed by using a two-way analysis of variance (ANOVA) [47]. The difference of treatment means was examined by the least significance difference (LSD) test using a 5\% level of significance using Statistical Package Statistix 8.1 (Analytical Software, 2105 Miller Landing Rd Tallahassee, FL, USA) and Origin 2021. Pearson correlation and a principal component analysis were conducted using Origin 2021 (OriginPro, Version 2021. OriginLab Corporation, Northampton, MA, USA).

\section{Results}

\subsection{Root Colonization}

Inoculation of AMF significantly $(p \leq 0.05)$ increased the colonization percentage irrespective of soil $\mathrm{Zn}$ level up to $60 \mathrm{mg} \mathrm{Zn} \mathrm{kg}^{-1}$ application; however, higher application resulted in decreased colonization percentage. Non-inoculated (NM) maize roots showed a maximum of $45 \%$ root AMF colonization, as shown in Figure 1. Conversely, AMF-inoculated (AM) maize plant roots showed higher AMF colonization (Figure 1). Colonization percentage was significantly $(p \leq 0.05)$ high, with an average of $45 \%$ in AMFinoculated plants irrespective of AMF inoculation, and $\mathrm{Zn}$ application reduced the AMF colonization rate after $20 \mathrm{mg} \mathrm{Zn} \mathrm{kg}{ }^{-1}$ application. A more drastic effect of $\mathrm{Zn}$ application was observed in Z0 + NM plants.
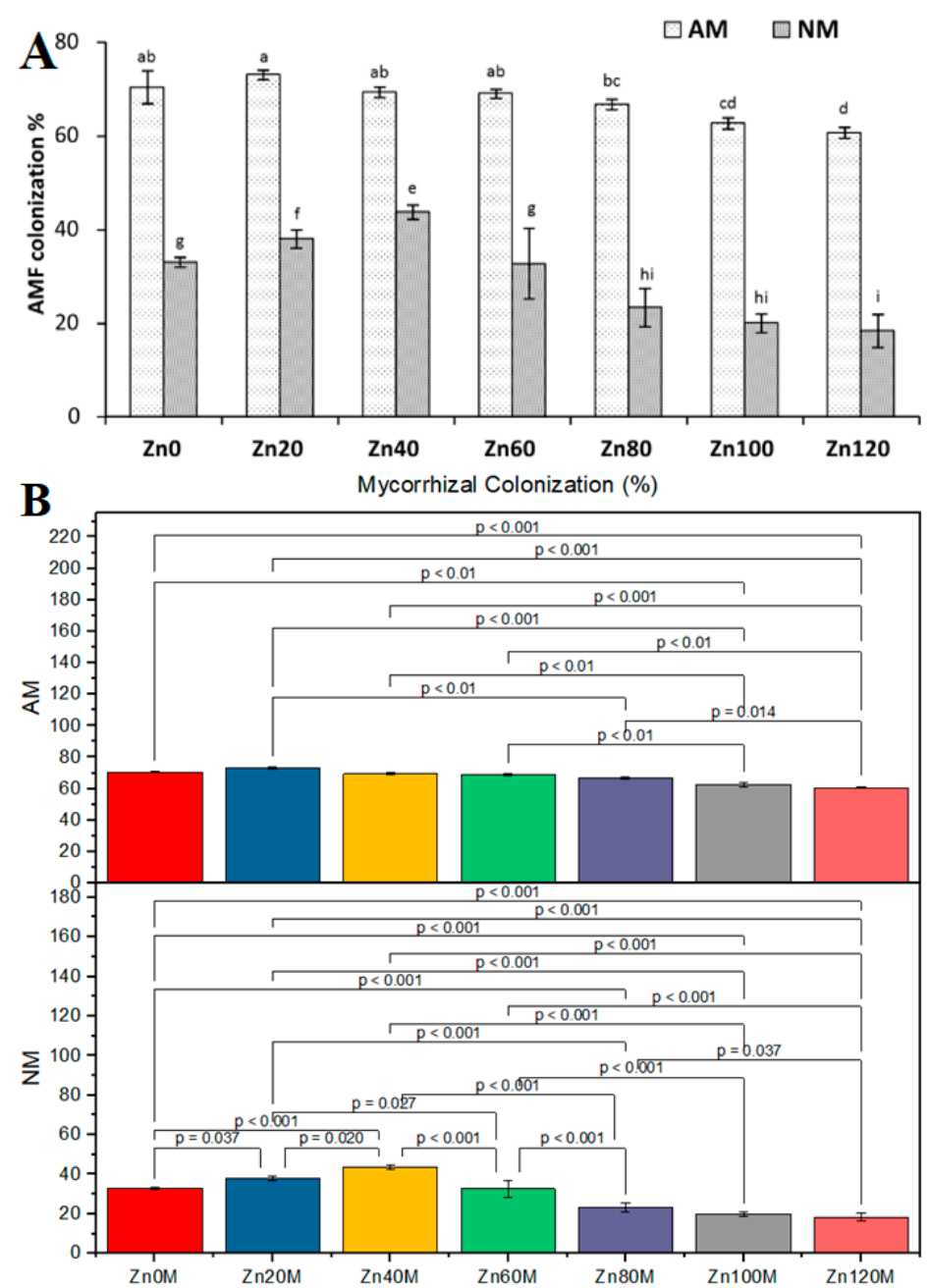

Figure 1. Effect of different application rates of $\mathrm{Zn}$ on arbuscular mycorrhizal fungi (AMF) colonization with and without AMF. Means are average of 3 replicates. Different values on graph (A) bars show a significant difference at $\alpha \leq 0.05$. Values on graph (B) bars are $p$-values computed using Fisher's least significance difference (LSD) test; $\alpha \leq 0.05$. 


\subsection{Plant Height}

Application of different levels of Zn with (AM) and without AMF (NM) significantly affected the maize plant height. The treatments Zn20 + AM and Zn40 + AM differed significantly compared to Z0 + AM and Z0 + NM in terms of plant height (Table 1; Figure 2). No significant change was observed among Zn20 + NM and Z0 + AM, but Zn20 + NM was significantly different to $Z 0+N M$. However, $Z n 40+N M$ remained significantly better than $\mathrm{Z} 0+\mathrm{AM}$. The treatments Zn80 + AM, Zn100 + AM, and Zn120 + AM significantly affected plant height compared to Z0 + AM. The same trend was also noted among Zn80 + NM, $\mathrm{Zn} 100+\mathrm{NM}$, and Zn120+NM compared to Z0 + NM. The maximum increase of $15 \%$ and $25 \%$ in plant height was observed in Zn20 + AM compared to Z0 + AM and Z0 + NM, respectively.

Table 1. Effect of different application rates of $\mathrm{Zn}$ with (AM) and without AMF (NM) on maize growth attributes. Values are means of three replicates. Different letters show significant difference at $p \leq 0.05$; LSD test.

\begin{tabular}{|c|c|c|c|c|c|c|}
\hline \multirow{2}{*}{ Treatment } & \multicolumn{2}{|c|}{ Plant Height (cm) } & \multicolumn{2}{|c|}{ Stem Girth (cm) } & \multicolumn{2}{|c|}{ No. of Leaves } \\
\hline & AM & NM & AM & NM & AM & NM \\
\hline $\begin{array}{c}\text { Control } \\
(\mathrm{Zn} 0)\end{array}$ & $160 c$ & $147 d$ & $2.7 \mathrm{ab}$ & $2.6 b c$ & $9.3 c$ & 8.3de \\
\hline Zn20 & $184 a$ & $158 \mathrm{c}$ & $2.8 \mathrm{a}$ & $2.7 \mathrm{~cd}$ & $12.6 \mathrm{a}$ & $9.3 c$ \\
\hline $\mathrm{Zn} 40$ & $182 \mathrm{ab}$ & $176 b$ & $2.6 \mathrm{~b}$ & $2.5 b$ & $12.0 \mathrm{a}$ & $11.0 \mathrm{~b}$ \\
\hline Zn60 & $149 d$ & $136 \mathrm{e}$ & $2.5 \mathrm{~d}$ & $2.4 \mathrm{e}$ & $9.1 \mathrm{~cd}$ & $8.5 \mathrm{cde}$ \\
\hline $\mathrm{Zn} 80$ & $138 \mathrm{ef}$ & $118 \mathrm{gh}$ & $2.4 \mathrm{e}$ & $2.3 \mathrm{f}$ & $9.0 \mathrm{~cd}$ & $8.0 \mathrm{ef}$ \\
\hline Zn100 & 132ef & $113 \mathrm{~h}$ & $2.3 \mathrm{f}$ & $2.1 \mathrm{~g}$ & $8.3 \mathrm{de}$ & $7.3 \mathrm{fg}$ \\
\hline Zn120 & $124 \mathrm{~g}$ & $111 \mathrm{fh}$ & $2.2 \mathrm{~g}$ & $1.9 \mathrm{~h}$ & $7.3 \mathrm{fg}$ & $7.0 \mathrm{f}$ \\
\hline $\mathrm{AM}$ & \multicolumn{2}{|c|}{$* * *$} & \multicolumn{2}{|c|}{$* * *$} & \multicolumn{2}{|c|}{$* * *$} \\
\hline Zinc & \multicolumn{2}{|c|}{$* * *$} & \multicolumn{2}{|c|}{$* * *$} & \multicolumn{2}{|c|}{$* * *$} \\
\hline $\mathrm{AM}^{*} \mathrm{Zn}$ & \multicolumn{2}{|c|}{ * } & \multicolumn{2}{|c|}{$* * *$} & \multicolumn{2}{|c|}{$* *$} \\
\hline
\end{tabular}

${ }^{*}(p \leq 0.005),{ }^{* *}(p \leq 0.01),{ }^{* * *}(p \leq 0.001)$.

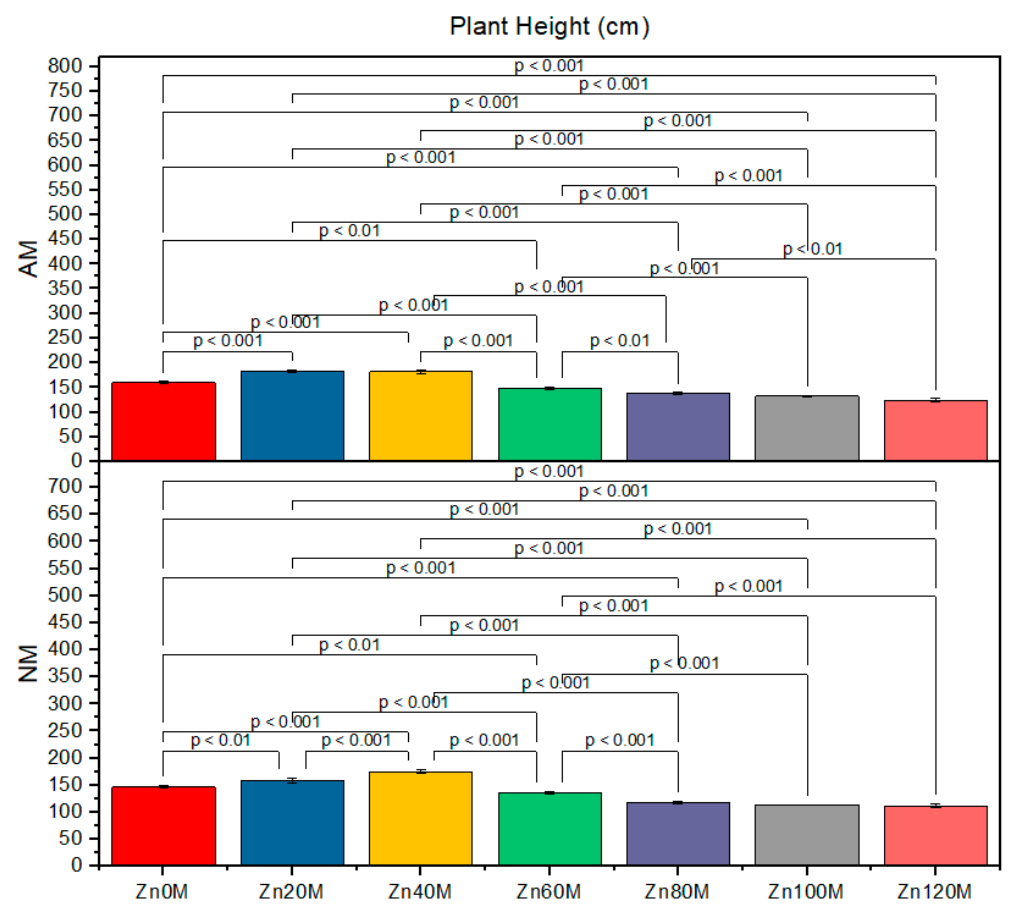

Figure 2. Effect of different application rates of $\mathrm{Zn}$ on maize plant height with and without AMF. Means are average of 3 replicates. Different values on bars are $p$-values computed using Fisher's LSD test; $\alpha \leq 0.05$. 


\subsection{Stem Girth}

Zinc application with (AM) and without AMF (NM) significantly affected maize stem girth. The treatment Zn20 + AM was significantly different compared to Z0 + NM for increased stem girth (Table 1; Figure 3). No significant change was observed among $\mathrm{Zn} 20+\mathrm{AM}, \mathrm{Zn} 40+\mathrm{AM}$, and $\mathrm{Z0}+\mathrm{AM}$ for stem girth. The treatments $\mathrm{Zn} 80+\mathrm{AM}$, $\mathrm{Zn} 100+\mathrm{AM}$, and Zn120 + AM significantly affected stem girth compared to Z0 + AM. The same trend was also noted among Zn80 + NM, Zn100 + NM, and Zn120 + NM compared to $\mathrm{Z} 0+\mathrm{NM}$. The maximum increase of $7.69 \%$ in stem girth was observed in Zn20 + AM over $\mathrm{Z} 0+\mathrm{NM}$.

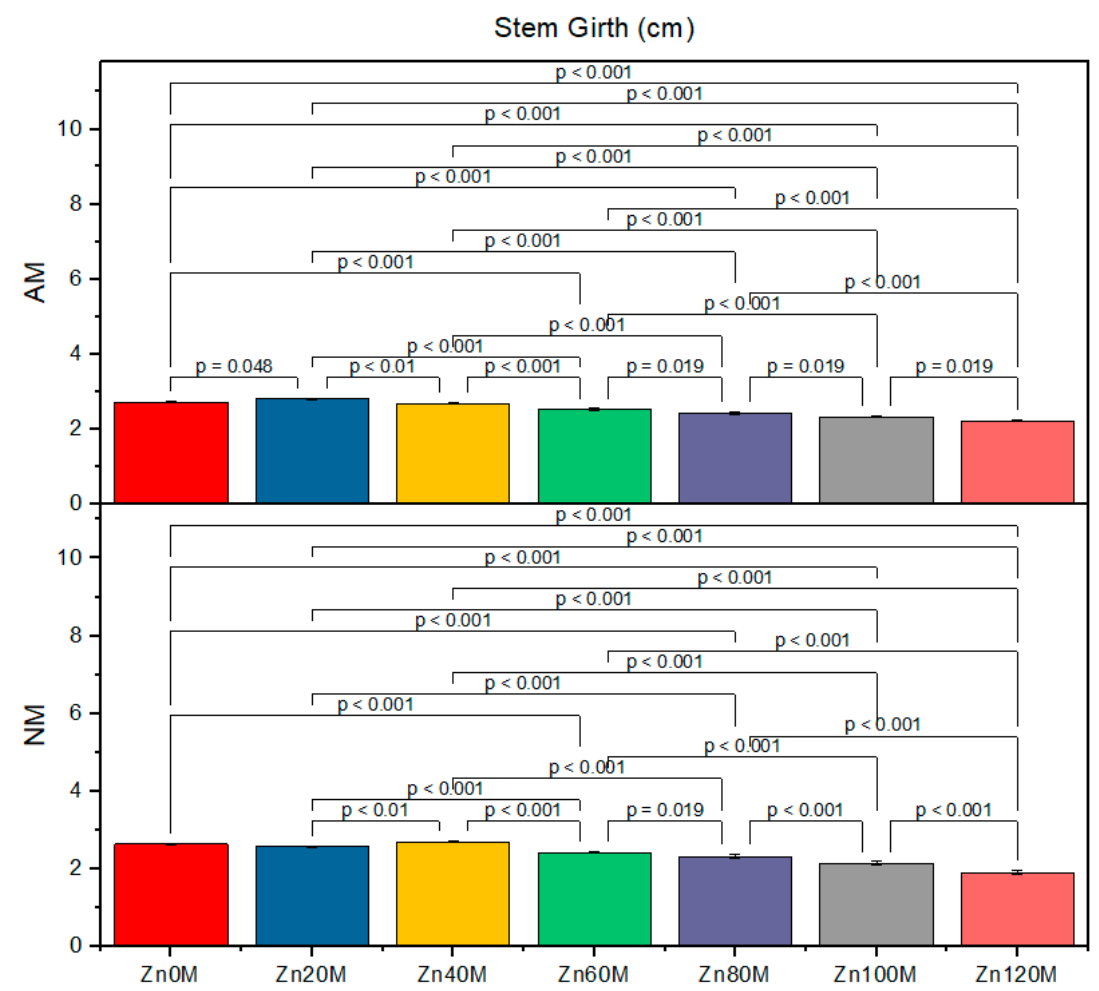

Figure 3. Effect of different application rates of $\mathrm{Zn}$ on maize stem girth with and without AMF. Means are average of 3 replicates. Different values on bars are $p$-values computed using Fisher's LSD test; $\alpha \leq 0.05$.

\subsection{Number of Leaves}

The interaction of Zn application and AMF inoculation significantly affected the number of maize leaves. Application of $\mathrm{Zn} 20+\mathrm{AM}$ and $\mathrm{Zn} 40+\mathrm{AM}$ increased the leaf number compared to Z0 + AM and Z0 + NM (Table 1; Figure 4). A significant change in the number of leaves was also observed among Zn20 + AM and Zn40 + AM compared to Z0 + AM. Treatments Zn100 + AM and Zn120 + AM significantly affected the number of leaves compared to Z0 + AM. The same trend was also observed among Zn100 + NM and Zn120 + NM compared to Z0 + NM. The maximum increase of $35.4 \%$ and $51.8 \%$ in the number of leaves was recorded in Zn20 + AM over Z0 + AM and Z0 + NM, respectively. 


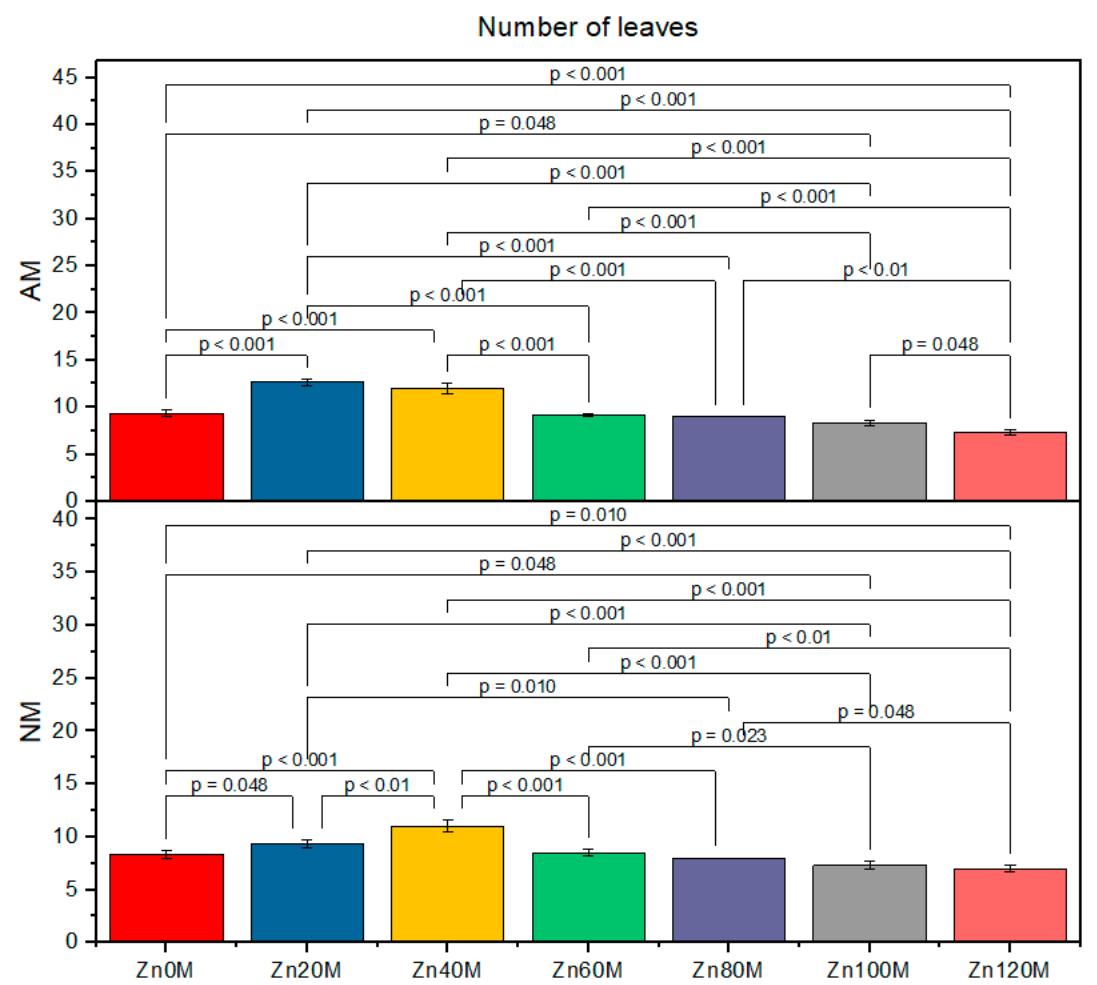

Figure 4. Effect of different application rates of $\mathrm{Zn}$ on maize number of leaves with and without AMF. Means are average of 3 replicates. Different values on bars are $p$-values were computed using Fisher's LSD test; $\alpha \leq 0.05$.

\subsection{Cob Weight}

The effect of the interaction of $\mathrm{Zn}$ dose with AMF inoculation significantly affected cob weight of maize. Cob weight differed between Zn20 + AM and Z0 + NM (Table 2; Figure 5). Cob weight was significantly higher with Zn20 + NM and Zn40 + NM compared with Z0 + NM. A significant change in cob weight was also observed among Zn20 + AM, Zn40 + AM, and Zn60 + AM treatments. Zn80 + AM, Zn100+ AM, and Zn120 + AM significantly affected cob weight compared to $\mathrm{Z} 0+\mathrm{AM}$. The same trend was also observed among Zn80 + NM, Zn100 + NM, and Zn120 + NM compared to Z0 + NM. The maximum increase of $4.39 \%$ and $12.8 \%$ in cob weight was recorded in Zn20 + AM over Z0 + AM and $\mathrm{Z} 0+\mathrm{NM}$, respectively.

Table 2. Effect of different application rates of $\mathrm{Zn}$ with and without AMF on growth attributes of maize. Values are means of three replicates. Different letters show significant difference at $p \leq 0.05$; LSD.

\begin{tabular}{|c|c|c|c|c|c|c|c|c|}
\hline \multirow{2}{*}{ Treatment } & \multicolumn{2}{|c|}{ Cob Weight (g) } & \multicolumn{2}{|c|}{ Cob Length $(\mathrm{cm})$} & \multicolumn{2}{|c|}{ 1000-Grain Weight (g) } & \multicolumn{2}{|c|}{ Biological Yield (t/ha) } \\
\hline & AM & NM & AM & NM & AM & NM & AM & NM \\
\hline $\begin{array}{c}\text { Control } \\
(\mathrm{Zn} 0)\end{array}$ & $227.6 \mathrm{bc}$ & $210.6 \mathrm{~d}$ & $16.5 a$ & $15.2 \mathrm{ef}$ & $152 d$ & $138 \mathrm{~g}$ & $4.17 \mathrm{c}$ & $3.79 \mathrm{~d}$ \\
\hline Zn20 & $232.6 \mathrm{ab}$ & $222.6 c$ & $20.8 \mathrm{a}$ & $16.4 \mathrm{~d}$ & $168 \mathrm{a}$ & $143 f$ & $5.93 a$ & $4.30 c$ \\
\hline $\mathrm{Zn} 40$ & $237.6 a$ & $227.6 \mathrm{bc}$ & $17.7 \mathrm{C}$ & $19.5 b$ & $163 b$ & $158 \mathrm{c}$ & $5.21 \mathrm{ab}$ & $5.06 \mathrm{~b}$ \\
\hline $\mathrm{Zn} 60$ & $224.6 c$ & $214.6 \mathrm{~d}$ & $15.5 \mathrm{e}$ & $14.5 \mathrm{f}$ & $158 \mathrm{c}$ & $158 \mathrm{c}$ & $5.00 \mathrm{c}$ & $4.88 \mathrm{e}$ \\
\hline Zn80 & $211.6 \mathrm{~d}$ & $201.6 \mathrm{e}$ & $15.5 \mathrm{e}$ & $14.5 \mathrm{f}$ & $138 \mathrm{~g}$ & $146 \mathrm{e}$ & $4.76 \mathrm{ef}$ & $4.03 \mathrm{gh}$ \\
\hline Zn100 & $203.3 e$ & $176 \mathrm{~g}$ & $15.5 \mathrm{e}$ & $14.5 f$ & $132 \mathrm{~h}$ & $122 \mathrm{i}$ & $3.78 \mathrm{ef}$ & $16.13 \mathrm{~h}$ \\
\hline Zn120 & $190 f$ & $139 \mathrm{~h}$ & $14.5 \mathrm{f}$ & $13.4 \mathrm{~g}$ & 128hi & $117 j$ & $3.72 \mathrm{fg}$ & $3.82 \mathrm{~h}$ \\
\hline $\mathrm{AM}$ & \multicolumn{2}{|c|}{$* * *$} & \multicolumn{2}{|c|}{$* * *$} & \multicolumn{2}{|c|}{$* * *$} & \multicolumn{2}{|c|}{$* * *$} \\
\hline Zinc & \multicolumn{2}{|c|}{$* * *$} & \multicolumn{2}{|c|}{$* * *$} & \multicolumn{2}{|c|}{$* * *$} & \multicolumn{2}{|c|}{$* * *$} \\
\hline $\mathrm{AM}^{*} \mathrm{Zn}$ & \multicolumn{2}{|c|}{$* * *$} & \multicolumn{2}{|c|}{$* * *$} & \multicolumn{2}{|c|}{$* * *$} & \multicolumn{2}{|c|}{ * } \\
\hline
\end{tabular}

${ }^{*}(p \leq 0.005),{ }^{* * *}(p \leq 0.001)$. 


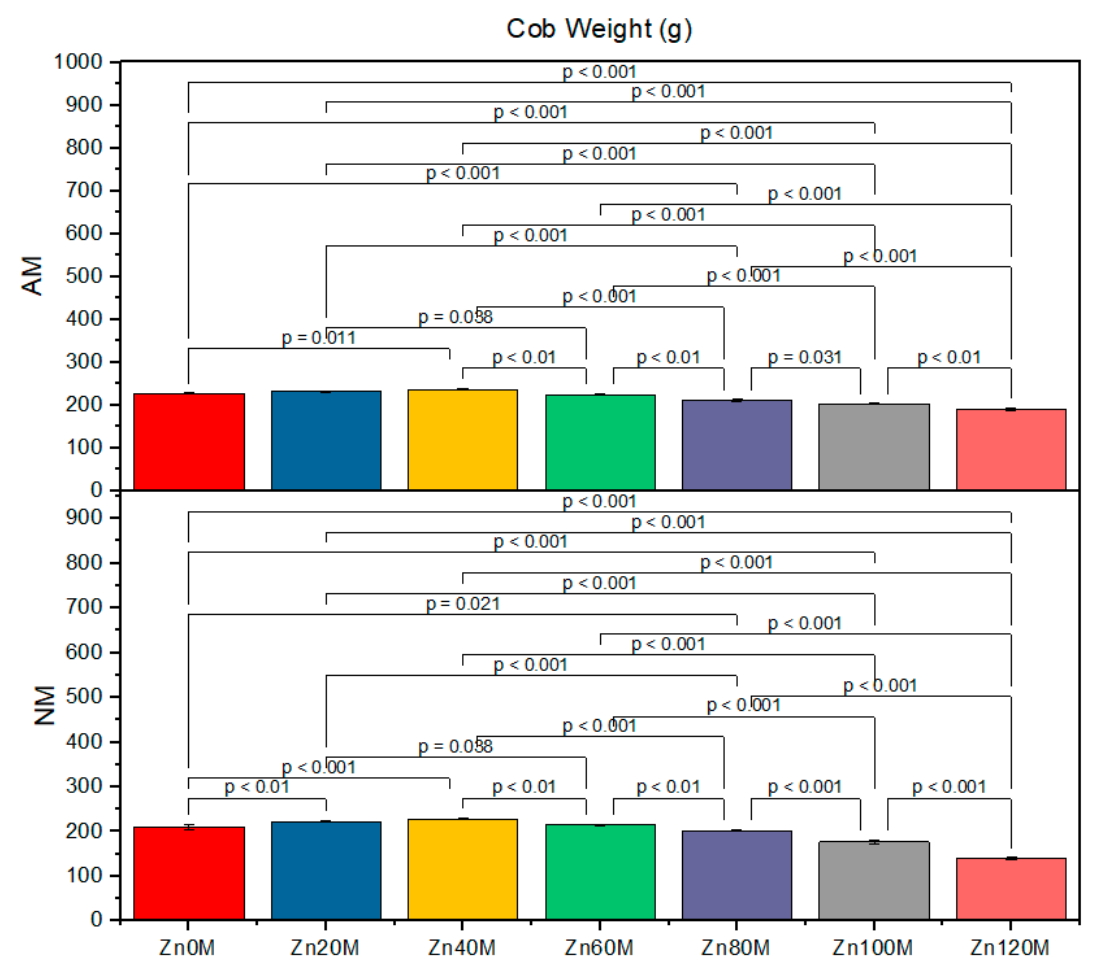

Figure 5. Effect of different application rates of $\mathrm{Zn}$ on maize cob weight with and without AMF. Means are average of 3 replicates. Different values on bars are $p$-values computed using Fisher's LSD test; $\alpha \leq 0.05$.

\subsection{Cob Length}

The interaction of $\mathrm{Zn}$ application with AMF inoculation significantly affected cob length of maize. The treatment Zn20 + AM significantly increased cob length over Z0 + NM (Table 2; Figure 6). The addition of Zn20 + NM and Zn40 + NM differed significantly for cob length from Zn0 + NM. A significant decrease was also noted among Zn40 + AM, $\mathrm{Zn} 60+\mathrm{AM}, \mathrm{Zn} 80+\mathrm{AM}$, and Zn100 + AM over Z0 + AM for cob length. Treatments Zn60 + NM, Zn80 + NM, Zn100 + NM, and Zn120 + NM also showed a significant decline in cob length compared to $\mathrm{Z} 0+\mathrm{NM}$. The maximum increase of $36.8 \%$ in cob length was observed in Zn20 + AM over Z0 + NM.

\subsection{0-Grain Weight}

$\mathrm{Zn}$ application and AMF inoculation significantly affected the 1000-grain weight of maize. The addition of Zn20 + NM, Zn40 + NM, Zn60 + NM, and Zn80 + NM significantly enhanced the 1000-grain weight of maize compared with Zn0 + NM (Table 2; Figure 7). A significant decrease was observed among Zn80 + AM, Zn100 + AM, and Zn120 + AM over Zn0 + AM for 1000-grain weight. The treatments Zn100 + NM and Zn120 + NM also showed a significant decline in 1000-grain weight over $Z 0+N M$. The maximum increase of $10.5 \%$ and $21.7 \%$ in 1000 -grain weight was observed in Zn20 + AM over Z0 + AM and $\mathrm{Z} 0+\mathrm{NM}$, respectively. 


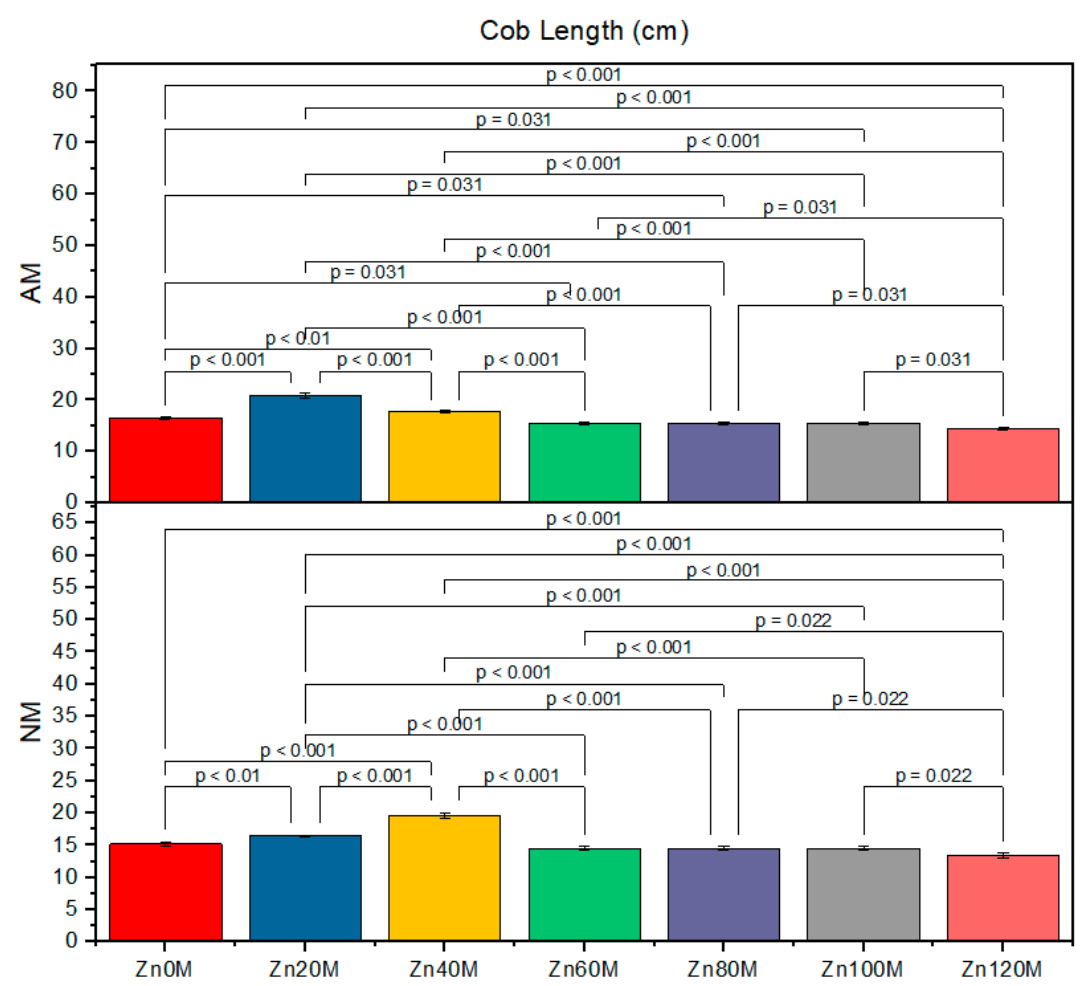

Figure 6. Effect of different application rates of $\mathrm{Zn}$ on maize cob length with and without AMF. Means are average of 3 replicates. Different values on bars are $p$-values computed using Fisher's LSD test; $\alpha \leq 0.05$.

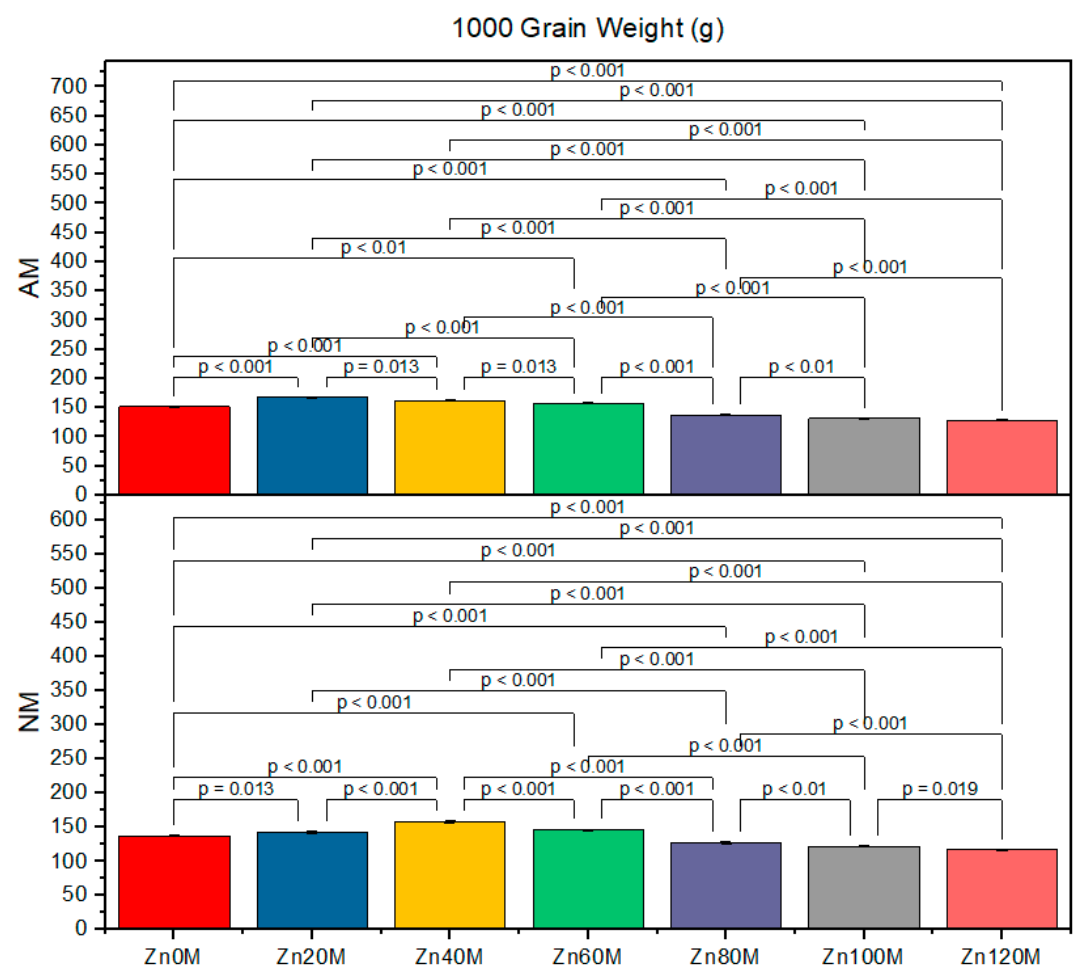

Figure 7. Effect of different application rates of Zn on maize 1000-grain weight with and without AMF. Means are average of 3 replicates. Different values on bars are $p$-values computed using Fisher's LSD test; $\alpha \leq 0.05$. 


\subsection{Grain Yield}

Zinc application and AMF inoculation significantly affected maize grain yield. The treatments Zn20 + NM and Zn40 + NM significantly enhanced the grain yield compared with Z0 + NM (Table 2; Figure 8). A significant decline in grain yield was observed when $\mathrm{Zn} 80+\mathrm{AM}, \mathrm{Zn} 100+\mathrm{AM}$, and Zn120 + AM were applied compared to Z0 + AM. The treatments Zn60 + NM, Zn80 + NM, Zn100 + NM, and Zn120 + NM also led to a significant decline in biological yield compared to Z0 + NM. The maximum increase of $42.2 \%$ and $56.5 \%$ in maize biological yield was observed in Zn20 + AM over Z0 + AM and Z0 + NM, respectively.

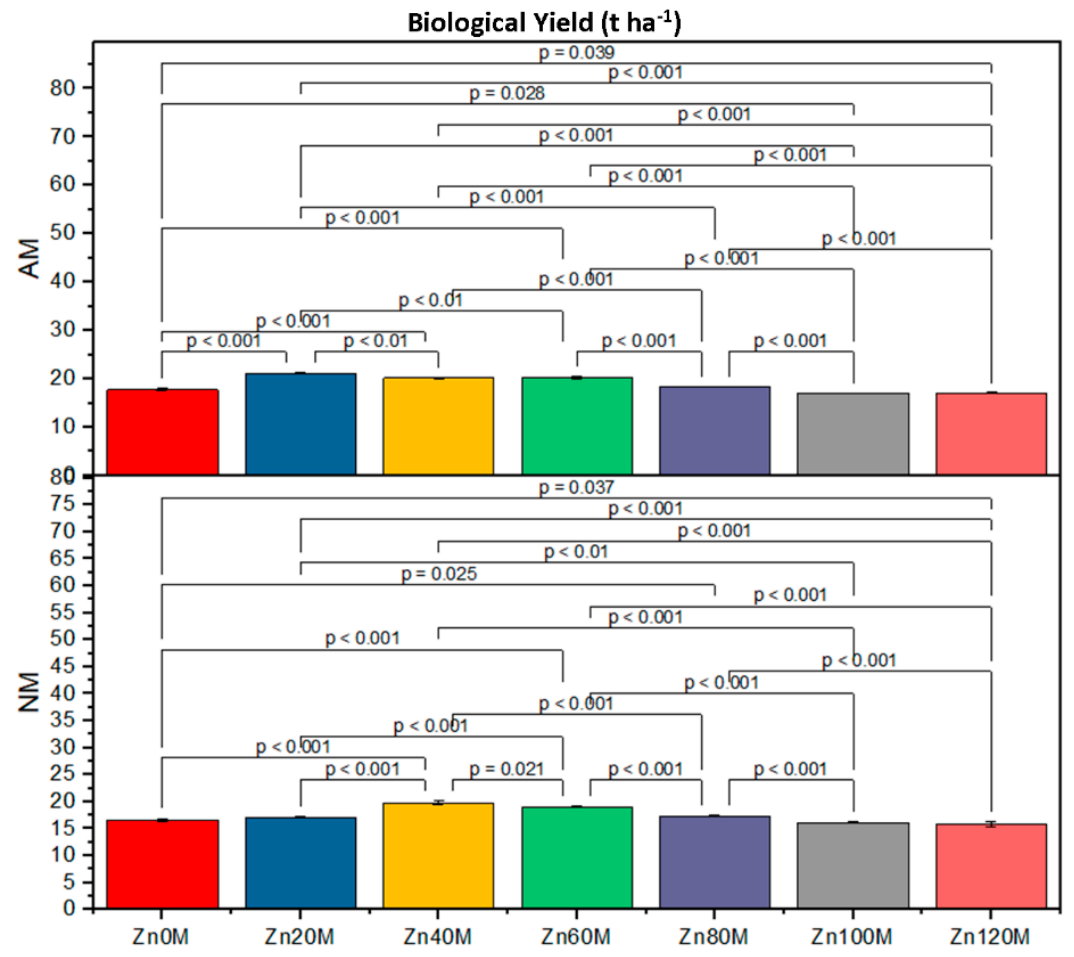

Figure 8. Effect of different application rates of $\mathrm{Zn}$ on maize biological yield with and without AMF. Means are average of 3 replicates. Different values on bars are $p$-values computed using Fisher's LSD test; $\alpha \leq 0.05$.

\subsection{Photosynthetic Rate}

Zinc application and AMF inoculation significantly affected the photosynthetic rate at the 45th day after germination. All the application rates of Zn significantly increased the photosynthetic rate in maize compared to Z0 + AM (Figure 9). The treatments Zn20 + NM, Zn40 + NM, Zn60 + NM, and Zn80 + NM also significantly enhanced the photosynthetic rate of maize compared to Z0 $+\mathrm{NM}$. The treatment Zn120+NM caused a significant decline in photosynthetic rate compared to Z0 + NM. 

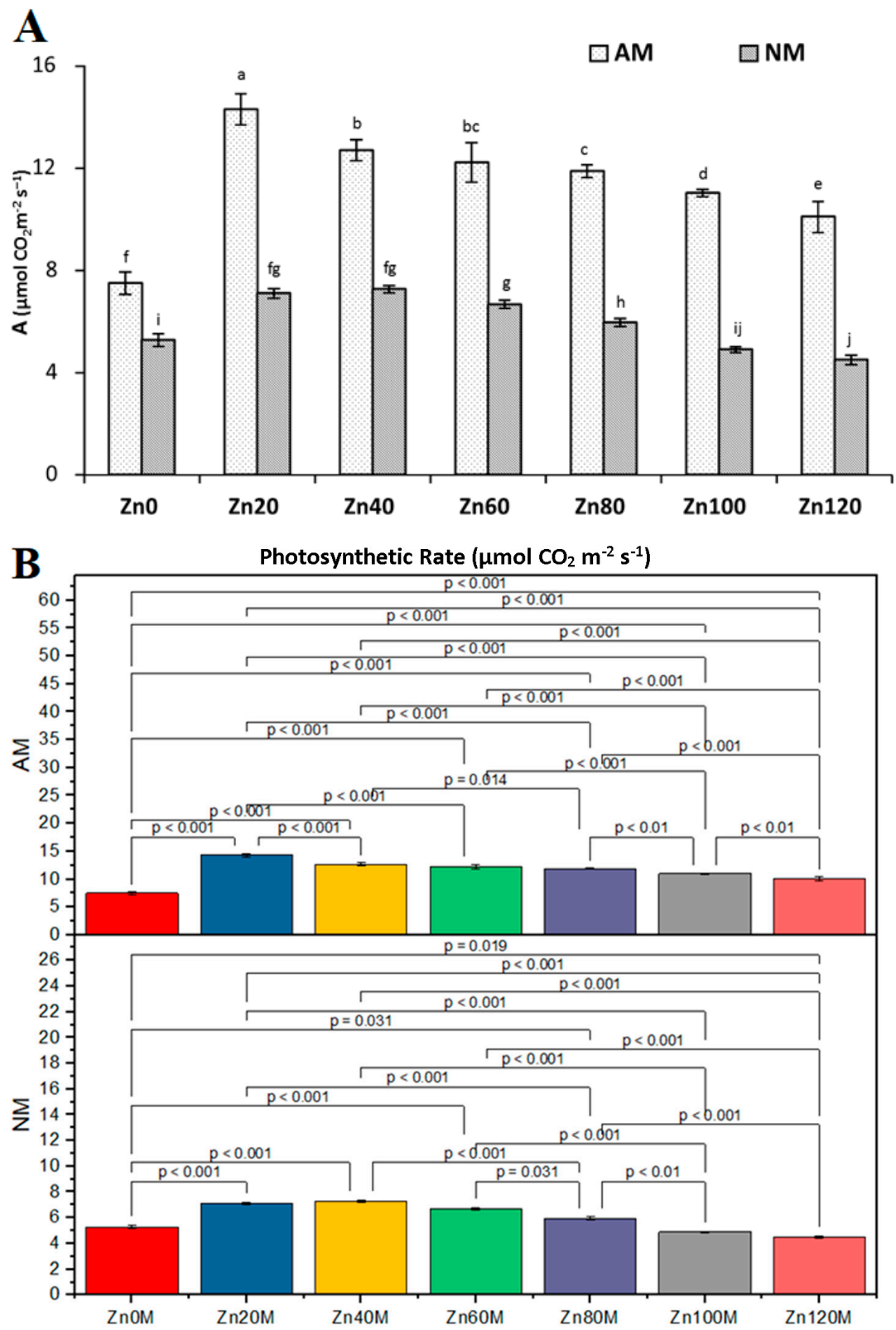

Figure 9. Effect of different application rates of $\mathrm{Zn}$ on the photosynthetic rate of maize with and without AMF. Means are average of 3 replicates. Different values on graph (A) bars show a significant difference at $\alpha \leq 0.05$. Values on graph (B) bars are $p$-values computed using Fisher's LSD test; $\alpha \leq 0.05$.

\subsection{Transpiration Rate}

Application of variable $\mathrm{Zn}$ rates with (AM) and without AMF (NM) led to significantly different results for maize transpiration rate at the 45th day after germination. All the application rates of Zn20 + AM, Zn40 + AM, Zn60 + AM, Zn80 + AM, Zn100 + AM, and Zn120 + AM significantly increased transpiration rate in maize over the Z0 + AM treatment (Figure 10). The treatments Zn20 + NM, Zn40 + NM, Zn60 + NM, and Zn80 + NM also enhanced the transpiration rate significantly in maize over $\mathrm{Z} 0+\mathrm{NM}$. The treatment Zn120 + NM caused a significant decrease in transpiration rate compared to Z0 + NM. 

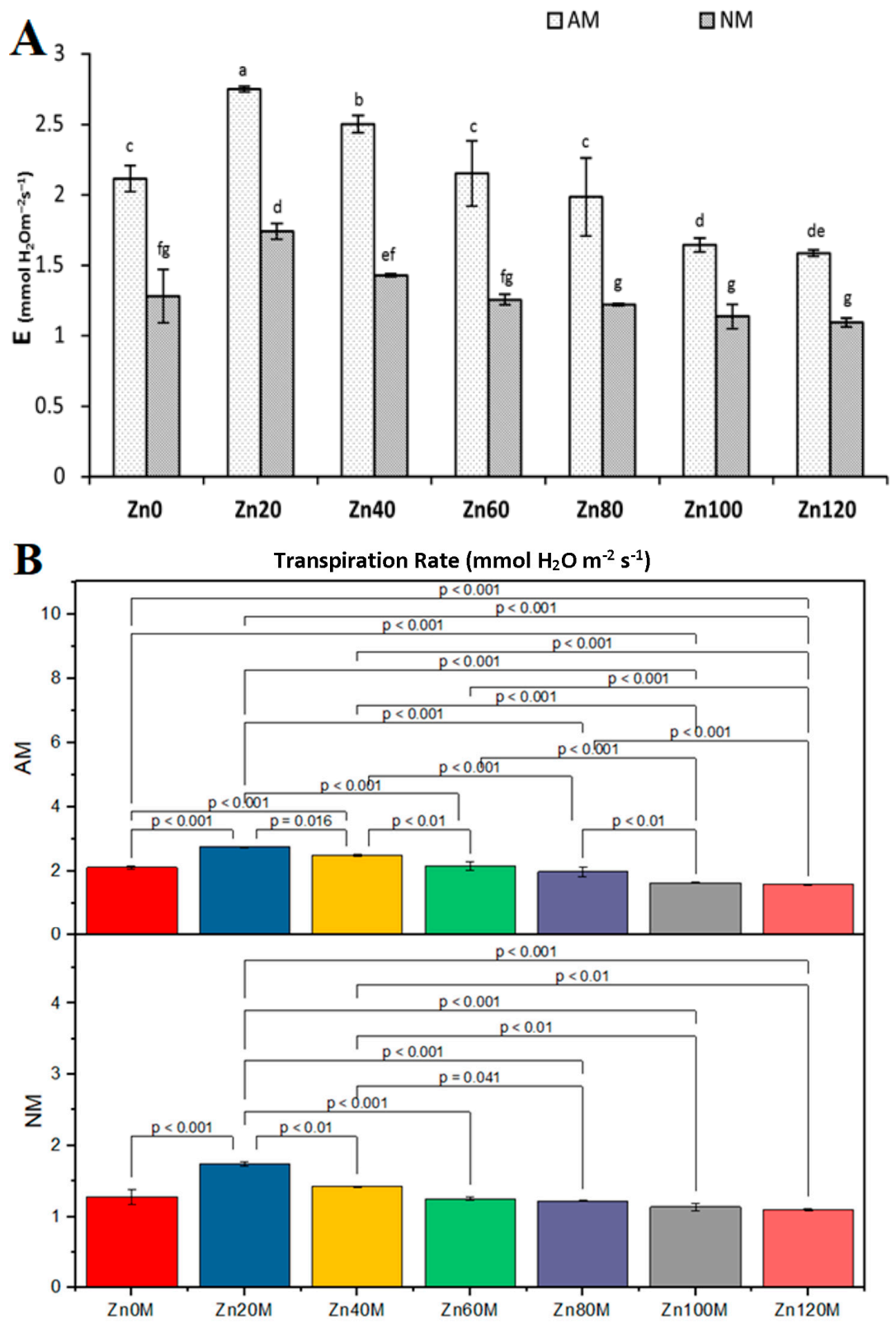

Figure 10. Effect of different application rates of $\mathrm{Zn}$ on the transpiration rate of maize with and without AMF. Means are average of 3 replicates. Different values on graph (A) bars show a significant difference at $\alpha \leq 0.05$. Values on graph (B) bars are $p$-values computed using Fisher's LSD test; $\alpha \leq 0.05$.

\subsection{Stomatal Conductance}

Application of variable Zn rates with (AM) and without AMF (NM) led to significantly different results for maize's stomatal conductance at the $45^{\text {th }}$ day after germination. The addition of Zn20 + AM significantly enhanced stomatal conductance in maize compared to $\mathrm{Z0}+\mathrm{AM}$ (Figure 11). It was noted that stomatal conductance was affected in the Zn60 + AM, Zn80 + AM, Zn100 + AM, and Zn120 + AM treatments compared to Z0 + AM. The treatment Zn20 + NM also enhanced stomatal conductance significantly in maize compared to NM. Application of Zn80 + NM, Zn100 + NM, and Zn120 + NM caused a significant decrease in stomatal conductance compared to Z0 + NM. 

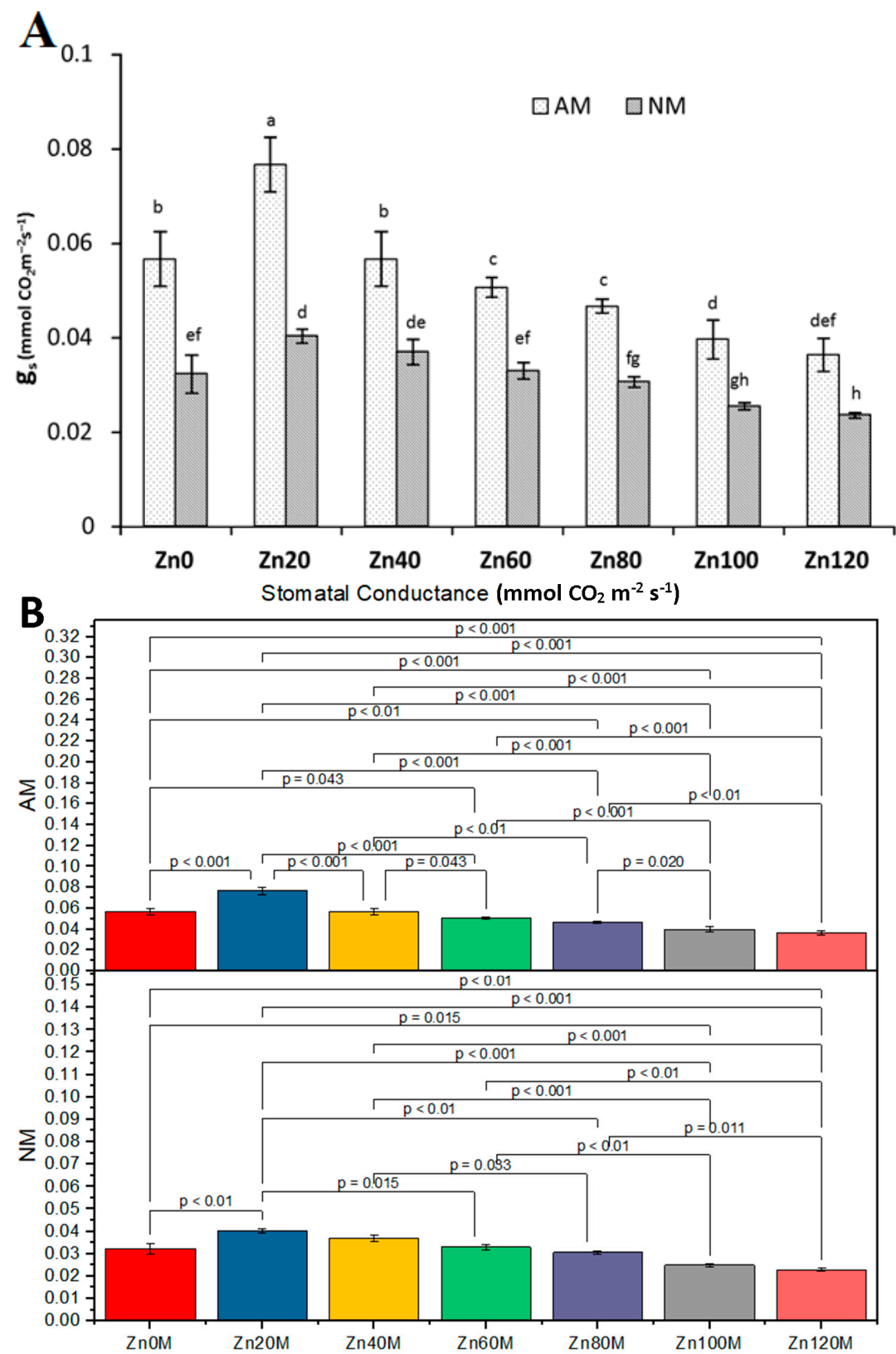

Figure 11. Effect of different application rates of $\mathrm{Zn}$ on stomatal conductance of maize with and without AMF. Means are average of 3 replicates. Different values on graph (A) bars show a significant difference at $\alpha \leq 0.05$. Values on graph (B) bars are $p$-values computed using Fisher's LSD test; $\alpha \leq 0.05$.

\subsection{Total Soluble Protein Concentration in Leaves}

Zinc application and AMF inoculation significantly affected the total soluble protein concentration in maize leaves. The addition of Zn20 + AM and Zn40 + AM significantly improved the total soluble protein content in maize compared to $\mathrm{Zn0}+\mathrm{AM}$ (Figure 12). It was observed that the total soluble protein content was affected in the Zn100 + AM and Zn120 + AM treatments compared to Z0 + AM. The treatments Zn20 + NM and Zn40 + $\mathrm{NM}$ also enhanced total soluble protein significantly in maize more than $Z 0+\mathrm{NM}$ did. The addition of Zn80 + NM, Zn100 + NM, and Zn120 + NM caused a significant decline in maize total soluble protein compared to $\mathrm{Z0}+\mathrm{NM}$. 

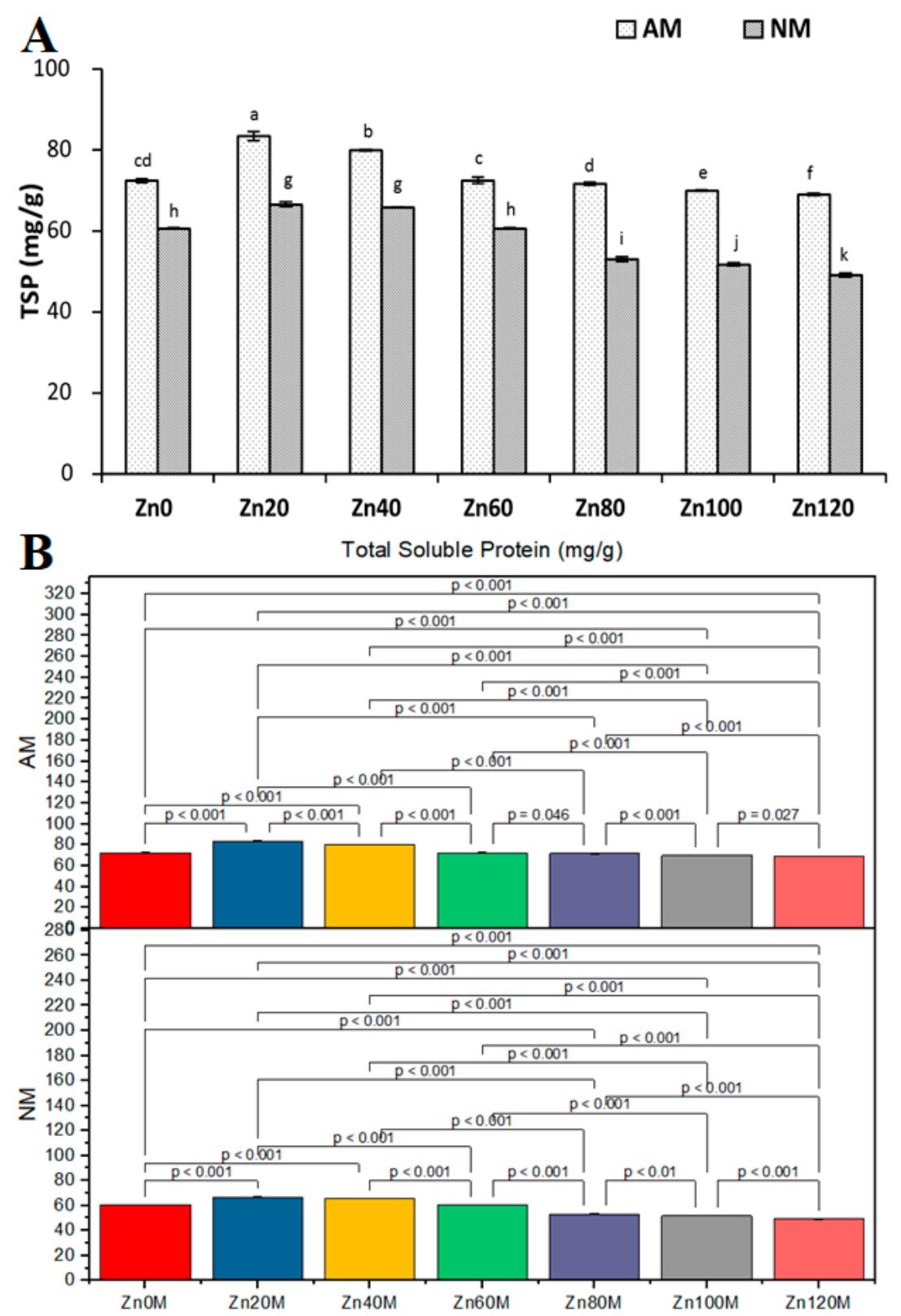

Figure 12. Effect of different application rates of Zn on the total soluble protein (TSP) contents of maize with and without AMF. Means are average of 3 replicates. Different values on graph (A) bars show a significant difference at $\alpha \leq 0.05$. Values on graph (B) bars are $p$-values computed using Fisher's LSD test; $\alpha \leq 0.05$.

\subsection{Pearson Correlation and Principal Component Analysis}

Pearson correlation showed that maize growth attributes were positively and significantly correlated with gas exchange attributes and yield components were affected by $\mathrm{Zn}$ application rate irrespective of AMF application (Figure 13). Principal component analyses showed that stomatal conductance, transpiration rate, total soluble protein, and biological yield were more closely associated with Zn20 (Figure 14B). Photosynthetic rate and AMF colonization were more closely associated with Zn60. All growth, yield, and gas exchange attributes were more closely associated with AMF (Figure 14B). 


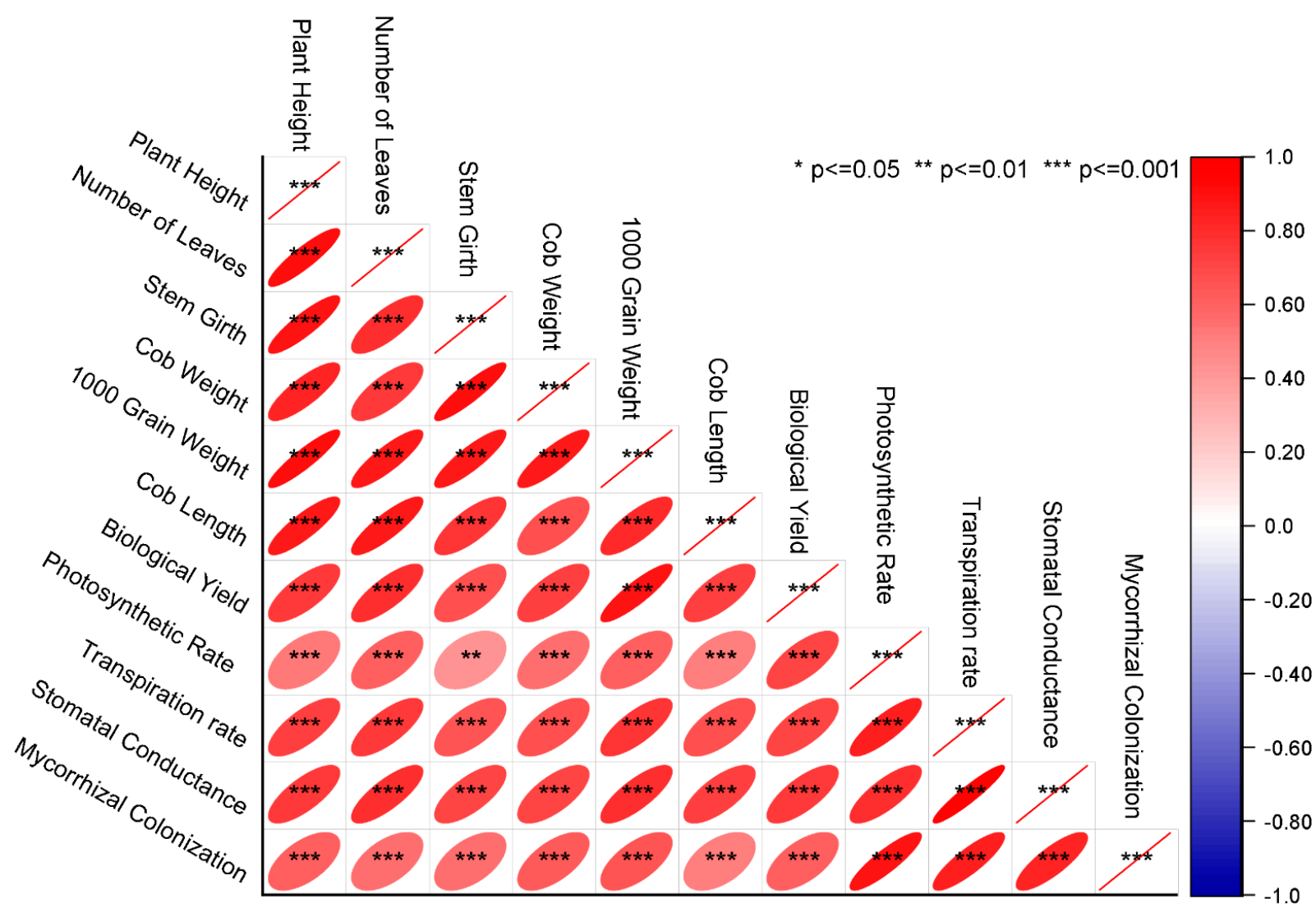

Figure 13. Pearson correlation for maize growth, yield, and gas exchange attributes affected by different application rates of Zn with and without AMF.

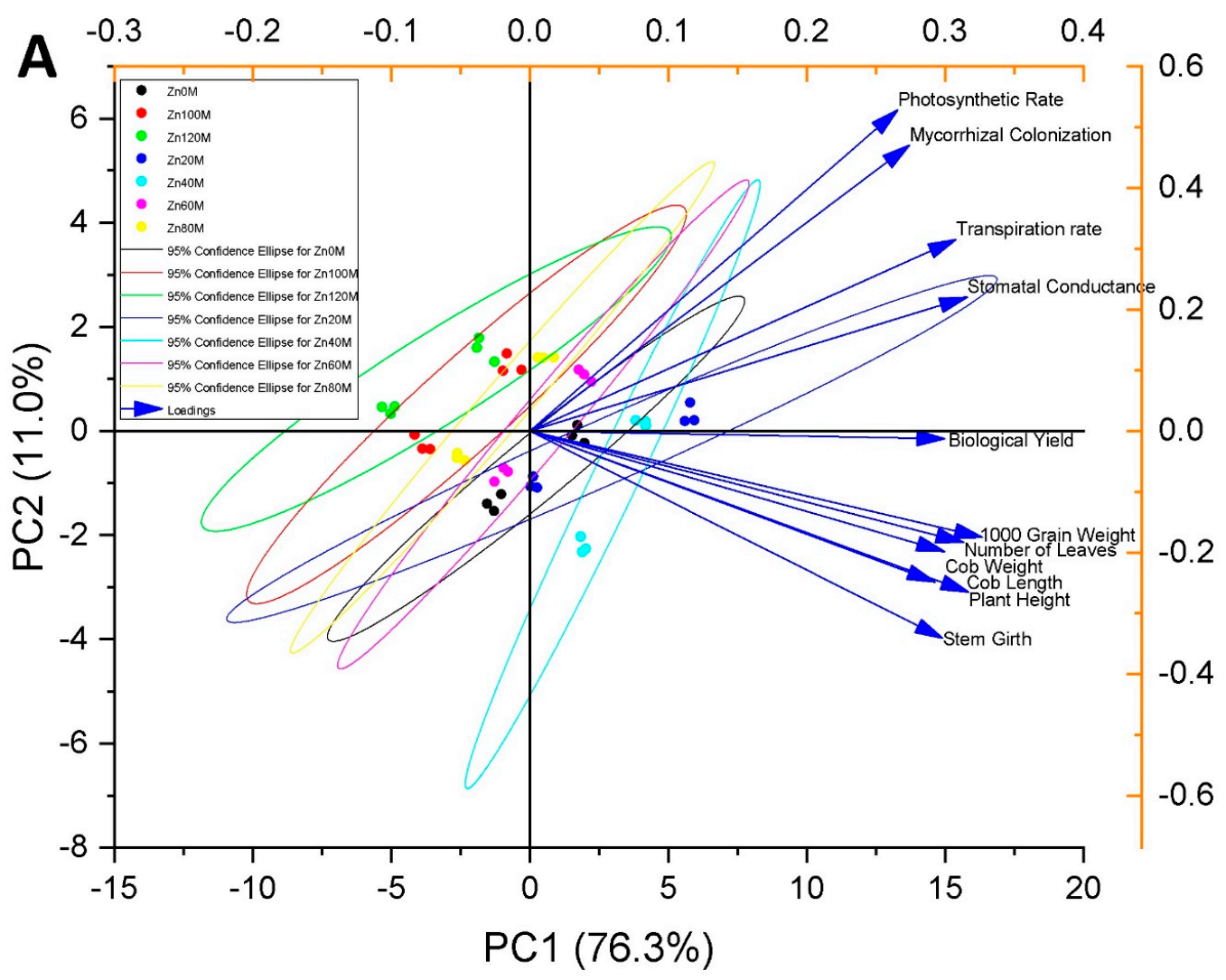

Figure 14. Cont. 


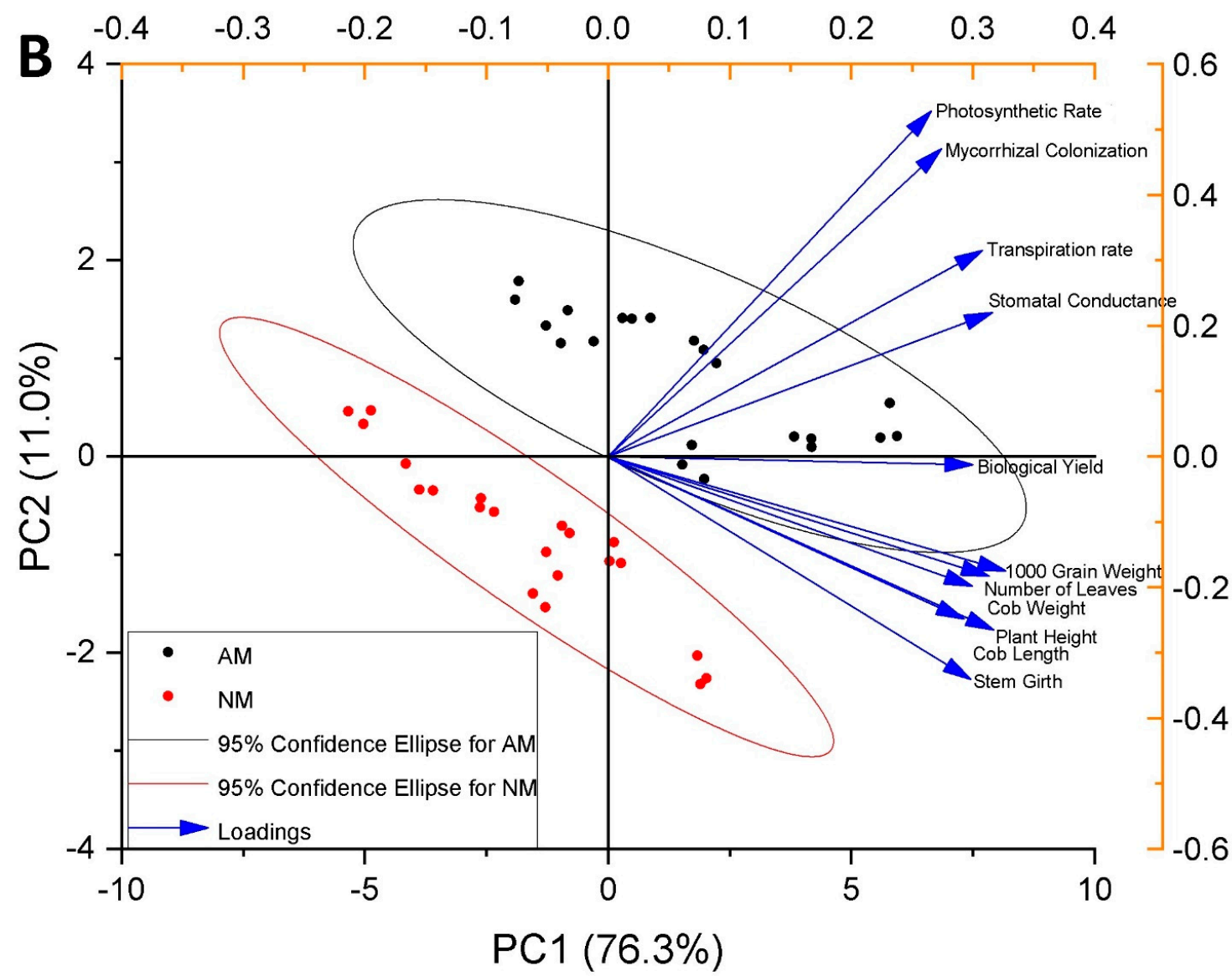

Figure 14. Principal component analysis for maize growth, yield, and gas exchange attributes affected by different application rates of $\mathrm{Zn}$ with and without AMF. (A) Different levels of $\mathrm{Zn}$ as a grouping component. (B) No AMF (NM) and $\mathrm{AMF}(\mathrm{AM})$ as a grouping component.

\section{Discussion}

Colonization of roots by AMF varies with $\mathrm{Zn}$ application and increases with the increase in the rate in Zn-deficient soil [48,49]. Conversely, high Zn $\left(80-120 \mathrm{mg} \mathrm{Zn} \mathrm{kg}^{-1}\right)$ supply reduced the AMF root colonization percentage of maize, and these results are in agreement with those of Watts-William et al. [50], Wang et al. [31], and Coccina et al. [14]. Lingua et al. [51] observed that at high soil Zn concentration, AMF colonization was suppressed owing to reduced hyphal growth and prevention of spore production and germination. High $\mathrm{Zn}$ concentration in roots mediates two kinds of responses, i.e., fungal and plant responses. Alteration in fungal response includes reduced spore germination, spore life length, and density of spores, growth of hyphae, and appressoria formation [52]. In plant responses, high $\mathrm{Zn}$ upregulates the plant defense system, alters the hormonal balance, and, most importantly, it alters the root exudates' composition [53,54]. Irrespective of AMF inoculation, high Zn supply negatively affects the plant growth parameters and yield $[31,50]$. Inoculated plants showed improved maize growth. AMF have a nutrient threshold level below which they upregulate nutrient transporter genes, and above this threshold, they impart a protective effect on plants and increase plant growth [55]. A detailed study by Paneque et al. [56] showed that AMF inoculation increased plant yield by $20 \%$. A similar result was also documented by Zhang et al. [57], whereby inoculation of $R$. irregularis increased yield by $17 \%$, and in another study of wheat, a $24 \%$ increase in grain yield was observed with high $\mathrm{Zn}$ application [14]. Another study also showed high yield in R. irregularis-inoculated plants at 100 and $500 \mathrm{mg} \mathrm{Zn} \mathrm{kg}^{-1}$ application [58]. AMF colonization rate was positively correlated with plant height, stem width, and cob weight and length. According to Monnet et al. [59], Zn deficiency adversely affects plant 
growth by minimizing photosynthesis and damaging chloroplast thylakoids and lightharvesting complex (LHC) proteins, leading to disorganization and disintegration of the chloroplast membrane. In our study, reduced plant height, stem girth, number of leaves, and other growth attributes were due to poor Zn uptake. Coccina et al. [14] described that improved growth due to $\mathrm{Zn}$ application is associated with increased $\mathrm{Zn}$ uptake by the plant. Application of $\mathrm{Zn}$ in deficient soil increased photosynthesis, transpiration, and stomatal conductance rate [60]. It might be due to an increase in total soluble protein (TSP) contents, which was also observed in the current study.

Our results are also supported by those of Liu et al. [61]. They documented an increased photosynthetic efficiency by increasing chlorophyll a and b concentrations due to Zn application in Zn-deficient soil [61]. Zinzala et al. [60] showed that many physiological parameters were negatively affected above $80 \mathrm{mg} \mathrm{Zn} \mathrm{kg}^{-1}$ soil application due to $\mathrm{Zn}$ toxicity [60]. We observed a reduction in the net photosynthetic rate (A) and transpiration rate (E) due to reduced stomatal conductance. However, no visual symptoms of Zn toxicity were observed in our study [62]. Sagardoy et al. [63] argued that Zn toxicity reduced the stomatal conductance (gs) severely $(76 \%)$, which limits other related physiological and chemical processes [63]. They also found that excess $\mathrm{Zn}$ led to alteration of the physical structure of mesophyll cells and stomata. Reduced photosynthesis was also due to the restricted activity of carbonic anhydrase enzyme [63]. According to Tobin [64], Zn is a crucial part of carbonic anhydrase (CA) in chloroplasts and cytoplasm [65]. CA activity becomes restricted under limited $\mathrm{Zn}$ uptake $[65,66]$. CA activity also controls $\mathrm{CO}_{2}$ diffusion in cell lipid phase to chloroplasts during photosynthesis $[67,68]$. According to Sharma et al. [69], CA activity restriction under Zn deficiency decreased stomatal conductance and transpiration rate.

Vassilev et al. [62] studied excess $\mathrm{Zn}$ in plant tissues, which reduced $\mathrm{Mg}^{2+}$ uptake, replaced $\mathrm{Mg}$ atoms, and disrupted chlorophyll structure and decreased photosynthetic rate [62]. Inoculation with AMF improved the total soluble protein content in maize [70,71]. The results of our study are in accordance with those of Nguyen et al. [71]. In soil with low $\mathrm{Zn}, \mathrm{AMF}$ increases carbonic anhydrase enzyme activity and enhances photosynthesis. In contrast, in soil with high Zn, AMF imparted a protective effect on plants by mitigating the $\mathrm{Zn}$ toxicity effect [71]. In this study, the results showed that AMF-inoculated plants improved the plant physiological response with high soil Zn compared to non-inoculated plants, and the results are in line with those of Wang et al. [31].

\section{Conclusions}

The application of $\mathrm{Zn} 20+\mathrm{AM}$ proved to be the most effective one for improving maize growth attributes cultivated in Zn-deficient conditions. A significant increase in the yield attributes of maize through the addition of $Z n 20+A M$ validated the efficacious functioning of the combined used of $\mathrm{Zn}$ and $\mathrm{AM}$ in terms of photosynthetic rate, gas exchange attributes, and stomatal conductance. Higher application rates of $\mathrm{Zn}$, i.e., 80, 100, and 120, induced adverse effects on maize growth, yield, and gas exchange attributes with $\mathrm{AM}$ and NM. It is recommended to apply Zn20 + AM to achieve better growth and yield of maize in Zn-deficient soils.

Author Contributions: Conceptualization, A.S. and M.A.A.; methodology, M.A.A.; software, S.D.; validation, S.D., M.A.A., and N.A.; formal analysis, A.S.; investigation, A.S.; resources, M.A.A.; data curation, A.S.; writing - original draft preparation, M.S., M.M.H., M.A.A., S.D., R.D., S.F., and F.H.; writing-review and editing, M.B., A.E.S., M.A.A., S.D., R.D., and S.F.; supervision, M.A.A. All authors have read and agreed to the published version of the manuscript.

Funding: This research was supported by Bahauddin Zakariya University, Multan, Pakistan, and Higher Education Commission (HEC), Islamabad, Pakistan. The authors are also very highly grateful to Taif University Researchers Supporting Project number (TURSP-2020/143), Saudi Arabia.

Institutional Review Board Statement: Not applicable.

Data Availability Statement: Not applicable. 
Acknowledgments: The authors are grateful to Taif University Researchers Supporting Project number (TURSP-2020/143), Saudi Arabia.

Conflicts of Interest: The authors declare no conflict of interest.

\section{References}

1. Hanif, N.Q.; Akhtar, N. Nutritional Evaluation of Maize Plant Fodder Grown in Spring and Autumn Season in Punjab, Pakistan. J. Bioresour. Manag. 2020, 7, 74-93. [CrossRef]

2. Tariq, M.; Iqbal, H. Maize in Pakistan-An overview. Kasetsart J. Nat. Sci. 2010, 44, 757-763.

3. Rafiullah, A.; Tariq, M.; Khan, F.; Shah, A.H.; Fahad, S.; Wahid, F.; Ali, J.; Adnan, M.; Ahmad, M.; Irfan, M.; et al. Effect of micronutrients foliar supplementation on the production and eminence of plum. Qual. Assur. Saf. Crop. Foods 2020, 12, 32-40. [CrossRef]

4. Tahir, F.A.; Ahamad, N.; Rasheed, M.K.; Danish, S. Effect of various application rate of zinc fertilizer with and without fruit waste biochar on the growth and Zn uptake in maize. Int. J. Biosci. 2018, 13, 159-166.

5. Bibi, F.; Saleem, I.; Ehsan, S.; Jamil, S.; Ullah, H.; Mubashir, M.; Kiran, S.; Ahmad, I.; Irshad, I.; Saleem, M.; et al. Effect of various application rates of phosphorus combined with different zinc rates and time of zinc application on phytic acid concentration and zinc bioavailability in wheat. Agric. Nat. Resour. 2020, 54, 265-272.

6. Imran, M.; Rehim, A.; Sarwar, N.; Hussain, S. Zinc bioavailability in maize grains in response of phosphorous-zinc interaction. J. Plant Nutr. Soil Sci. 2016, 179, 60-66. [CrossRef]

7. Imran, M.; Rehim, A. Zinc fertilization approaches for agronomic biofortification and estimated human bioavailability of zinc in maize grain. Arch. Agron. Soil Sci. 2017, 63, 106-116. [CrossRef]

8. Kumar, R.; Singh, M.; Meena, B.S.; Ram, H.; Parihar, C.M.; Kumar, S.; Yadav, M.R.; Meena, R.K.; Kumar, U.; Meena, V.K. Zinc management effects on quality and nutrient yield of fodder maize (Zea mays). Indian J. Agric. Sci. 2017, 87, $1013-1017$.

9. Obaid, E.A.; Al-hadethi, M.E.A. Effect of Foliar Application with Manganese and Zinc on Pomegranate Growth, Yield and Fruit Quality. J. Hortic. Sci. Ornam. Plants 2013, 5, 41-45.

10. Alloway, B.J. Zinc in Soils and Crop Nutrition; International Zinc Association: Brussels, Belgium, 2008; ISBN 978-90-8133-310-8.

11. Iratkar, A.G.; Giri, J.D.; Kadam, M.M.; Giri, J.N.; Dabhade, M.B. Distribution of DTPA extractable micronutrients and their relationship with soil properties in soil of Parsori watershed of Nagpur district of Maharashtra. Asian J. Soil Sci. 2014, 9, 297-299.

12. Cakmak, I. Enrichment of cereal grains with zinc: Agronomic or genetic biofortification? Plant Soil 2008, 302, 1-17. [CrossRef]

13. Mumtaz, M.Z.; Ahmad, M.; Jamil, M.; Hussain, T. Zinc solubilizing Bacillus spp. potential candidates for biofortification in maize. Microbiol. Res. 2017, 202, 51-60. [CrossRef]

14. Coccina, A.; Cavagnaro, T.R.; Pellegrino, E.; Ercoli, L.; McLaughlin, M.J.; Watts-Williams, S.J. The mycorrhizal pathway of zinc uptake contributes to zinc accumulation in barley and wheat grain. BMC Plant Biol. 2019, 19, 133. [CrossRef]

15. Danish, S.; Younis, U.; Akhtar, N.; Ameer, A.; Ijaz, M.; Nasreen, S.; Huma, F.; Sharif, S.; Ehsanullah, M. Phosphorus solubilizing bacteria and rice straw biochar consequence on maize pigments synthesis. Int. J. Biosci. 2015, 5, 31-39.

16. Danish, S.; Zafar-ul-Hye, M. Co-application of ACC-deaminase producing PGPR and timber-waste biochar improves pigments formation, growth and yield of wheat under drought stress. Sci. Rep. 2019, 9, 5999. [CrossRef]

17. Zafar-Ul-Hye, M.; Hussain, N.M.; Danish, S.; Aslam, U.; Zahir, Z.A. Multi-Strain bacterial inoculation of enterobacter cloacae, serratia ficaria and burkholderia phytofirmans with fertilizers for enhancing resistance in wheat against salinity stress. Pak. J. Bot. 2019, 51, 1839-1846. [CrossRef]

18. Danish, S.; Zafar-Ul-Hye, M.; Hussain, S.; Riaz, M.; Qayyum, M.F. Mitigation of drought stress in maize through inoculation with drought tolerant ACC deaminase containing PGPR under axenic conditions. Pak. J. Bot. 2020, 52, 49-60. [CrossRef]

19. Danish, S.; Zafar-ul-Hye, M.; Fahad, S.; Saud, S.; Brtnicky, M.; Hammerschmiedt, T.; Datta, R. Drought stress alleviation by ACC deaminase producing Achromobacter xylosoxidans and Enterobacter cloacae, with and without timber waste biochar in maize. Sustainability 2020, 12, 6286. [CrossRef]

20. Zafar-ul-Hye, M.; Tahzeeb-ul-Hassan, M.; Abid, M.; Fahad, S.; Brtnicky, M.; Dokulilova, T.; Datta, R.; Danish, S. Potential role of compost mixed biochar with rhizobacteria in mitigating lead toxicity in spinach. Sci. Rep. 2020, 10, 69183. [CrossRef] [PubMed]

21. Zafar-ul-Hye, M.; Tahzeeb-ul-Hassan, M.; Wahid, A.; Danish, S.; Khan, M.J.; Fahad, S.; Brtnicky, M.; Hussain, G.S.; Battaglia, M.L.; Datta, R. Compost mixed fruits and vegetable waste biochar with ACC deaminase rhizobacteria can minimize lead stress in mint plants. Sci. Rep. 2021, 11. [CrossRef] [PubMed]

22. Abbas, M.; Anwar, J.; Zafar-ul-Hye, M.; Khan, R.I.; Saleem, M.; Rahi, A.A.; Danish, S.; Datta, R. Effect of Seaweed Extract on Productivity and Quality Attributes of Four Onion Cultivars. Horticulturae 2020, 6, 28. [CrossRef]

23. Izhar Shafi, M.; Adnan, M.; Fahad, S.; Wahid, F.; Khan, A.; Yue, Z.; Danish, S.; Zafar-ul-Hye, M.; Brtnicky, M.; Datta, R. Application of Single Superphosphate with Humic Acid Improves the Growth, Yield and Phosphorus Uptake of Wheat (Triticum aestivum L.) in Calcareous Soil. Agronomy 2020, 10, 1224. [CrossRef]

24. Ullah, A.; Ali, M.; Shahzad, K.; Ahmad, F.; Iqbal, S.; Habib, M.; Rahman, U.; Ahmad, S.; Iqbal, M.M. Impact of Seed Dressing and Soil Application of Potassium Humate on Cotton Plants Productivity and Fiber Quality. Plants 2020, 9, 1444. [CrossRef] [PubMed]

25. Zafar-ul-hye, M.; Naeem, M.; Danish, S.; Khan, M.J.; Fahad, S.; Datta, R.; Brtnicky, M.; Kintl, A.; Hussain, M.S.; El-esawi, M.A. Effect of cadmium-tolerant rhizobacteria on growth attributes and chlorophyll contents of bitter gourd under cadmium toxicity. Plants 2020, 9, 1386. [CrossRef] [PubMed] 
26. Zafar-Ul-hye, M.; Naeem, M.; Danish, S.; Fahad, S.; Datta, R.; Abbas, M.; Rahi, A.A.; Brtnicky, M.; Holátko, J.; Tarar, Z.H.; et al. Alleviation of cadmium adverse effects by improving nutrients uptake in bitter gourd through cadmium tolerant rhizobacteria. Environments 2020, 7, 54. [CrossRef]

27. Adnan, M.; Fahad, S.; Zamin, M.; Shah, S.; Mian, I.A.; Danish, S.; Zafar-ul-Hye, M.; Battaglia, M.L.; Naz, R.M.M.; Saeed, B.; et al. Coupling Phosphate-Solubilizing Bacteria with Phosphorus Supplements Improve Maize Phosphorus Acquisition and Growth under Lime Induced Salinity Stress. Plants 2020, 9, 900. [CrossRef] [PubMed]

28. Pathan, S.I.; Větrovský, T.; Giagnoni, L.; Datta, R.; Baldrian, P.; Nannipieri, P.; Renella, G. Microbial expression profiles in the rhizosphere of two maize lines differing in N use efficiency. Plant Soil 2018, 433, 401-413. [CrossRef]

29. Wahid, F.; Fahad, S.; Danish, S.; Adnan, M.; Yue, Z.; Saud, S.; Siddiqui, M.H.; Brtnicky, M.; Hammerschmiedt, T.; Datta, R. Sustainable management with mycorrhizae and phosphate solubilizing bacteria for enhanced phosphorus uptake in calcareous soils. Agriculture 2020, 10, 334. [CrossRef]

30. Smith, S.E.; Read, D.J. Mycorrhizal Symbiosis, 3rd ed.; Academic Press; Elsevier: New York, NY, USA, 2008; Volume 137, ISBN 9780123705266.

31. Wang, F.; Liu, X.; Shi, Z.; Tong, R.; Adams, C.A.; Shi, X. Arbuscular mycorrhizae alleviate negative effects of zinc oxide nanoparticle and zinc accumulation in maize plants $\{\backslash$ textendash $\}$ A soil microcosm experiment. Chemosphere 2016, 147, 88-97. [CrossRef]

32. Wang, F.; Jing, X.; Adams, C.A.; Shi, Z.; Sun, Y. Decreased $\{\mathrm{ZnO}\}$ nanoparticle phytotoxicity to maize by arbuscular mycorrhizal fungus and organic phosphorus. Environ. Sci. Pollut. Res. 2018, 25, 23736-23747. [CrossRef] [PubMed]

33. Jansa, J.; Mozafar, A.; Frossard, E. Long-distance transport of $\mathrm{P}$ and $\mathrm{Zn}$ through the hyphae of an arbuscular mycorrhizal fungus in symbiosis with maize. Agronomie 2003, 23, 481-488. [CrossRef]

34. Watts-Williams, S.J.; Smith, F.A.; McLaughlin, M.J.; Patti, A.F.; Cavagnaro, T.R. How important is the mycorrhizal pathway for plant Zn uptake? Plant Soil 2015, 390, 157-166. [CrossRef]

35. Rhoades, J.D. Salinity: Electrical Conductivity and Total Dissolved Solids. In Methods of Soil Analysis, Part 3, Chemical Methods; Sparks, D.L., Page, A.L., Helmke, P.A., Loeppert, R.H., Soltanpour, P.N., Tabatabai, M.A., Johnston, C.T., Sumner, M.E., Eds.; Soil Science Society of America: Madison, WI, USA, 1996; Volume 5, pp. 417-435.

36. Page, A.L.; Miller, R.H.; Keeny, D.R. Soil pH and lime requirement. In Methods of Soil Analysis; American Society of Agronomy: Madison, MI, USA, 1982; pp. 199-208.

37. Kuo, S. Phosphorus. In Methods of Soil Analysis Part 3: Chemical Methods; Sparks, D.L., Page, A.L., Helmke, P.A., Loeppert, R.H., Soltanpour, P.N., Tabatabai, M.A., Johnston, C.T., Sumner, M.E., Eds.; John Wiley \& Sons, Ltd.: Madison, WI, USA, 1996; pp. 869-919.

38. Pratt, P.F. Potassium. In Methods of Soil Analysis: Part 2 Chemical and Microbiological Properties, 9.2; Norman, A.G., Ed.; John Wiley \& Sons, Ltd.: Hoboken, NJ, USA, 1965; pp. 1022-1030.

39. Sparks, D.L.; Page, A.L.; Helmke, P.A.; Loeppert, R.H.; Nelson, D.W.; Sommers, L.E. Total Carbon, Organic Carbon, and Organic Matter. In Methods of Soil Analysis Part 3-Chemical Methods; Soil Science Society of America; American Society of Agronomy; John Wiley \& Sons, Ltd.: Madison, WI, USA, 1996; pp. 961-1010.

40. Bremner, M. Chapter 37: Nitrogen-Total. Methods Soil Anal. Part Chem. Methods SSSA B. Ser. 1996, 5, $1085-1121$.

41. Danish, S.; Zafar-ul-Hye, M.; Mohsin, F.; Hussain, M. ACC-deaminase producing plant growth promoting rhizobacteria and biochar mitigate adverse effects of drought stress on maize growth. PLoS ONE 2020, 15, e0230615. [CrossRef] [PubMed]

42. Nazar, R.; Khan, M.I.R.; Iqbal, N.; Masood, A.; Khan, N.A. Involvement of ethylene in reversal of salt-inhibited photosynthesis by sulfur in mustard. Physiol. Plant. 2014, 152, 331-344. [CrossRef]

43. Danish, S.; Zafar-ul-Hye, M.; Hussain, M.; Shaaban, M.; Núñez-delgado, A. Rhizobacteria with ACC-Deaminase Activity Improve Nutrient Uptake, Chlorophyll Contents and Early Seedling Growth of Wheat under PEG- Induced Osmotic Stress. Int. J. Agric. Biol. 2019, 21, 1212-1220.

44. Bradford, M.M. A rapid and sensitive method for the quantitation of microgram quantities of protein using the principle of protein dye binding. Anal. Biochem. 1976, 72, 248-254. [CrossRef]

45. GIOVANNETTI, M.; MOSSE, B. An evaluation of techniques for measuring vesicular arbuscular mycorrhizal infection in roots. New Phytol. 1980, 84, 489-500. [CrossRef]

46. Phillips, J.M.; Hayman, D.S. Improved procedures for clearing roots and staining parasitic and vesicular-arbuscular mycorrhizal fungi for rapid assessment of infection. Trans. Br. Mycol. Soc. 1970, 55, 158-161, IN16-IN18. [CrossRef]

47. Steel, R.G.; Torrie, J.H.; Dickey, D.A. Principles and Procedures of Statistics: A Biometrical Approach, 3rd ed.; McGraw Hill Book International Co.: Singapore, 1997.

48. Lee, Y.-J.; George, E. Contribution of Mycorrhizal Hyphae to the Uptake of Metal Cations by Cucumber Plants at Two Levels of Phosphorus Supply. Plant Soil 2005, 278, 361-370. [CrossRef]

49. Zhu, Y.; Christie, P.; Laidlaw, A.S. Uptake of Zn by arbuscular mycorrhizal white clover from Zn-contaminated soil. Chemosphere 2001, 42, 193-199. [CrossRef]

50. Watts-Williams, S.J.; Patti, A.F.; Cavagnaro, T.R. Arbuscular mycorrhizas are beneficial under both deficient and toxic soil zinc conditions. Plant Soil 2013, 371, 299-312. [CrossRef]

51. Lingua, G.; Franchin, C.; Todeschini, V.; Castiglione, S.; Biondi, S.; Burlando, B.; Parravicini, V.; Torrigiani, P.; Berta, G. Arbuscular mycorrhizal fungi differentially affect the response to high zinc concentrations of two registered poplar clones. Environ. Pollut. 2008, 153, 137-147. [CrossRef] [PubMed] 
52. Pawlowska, T.E.; Charvat, I. Heavy-Metal Stress and Developmental Patterns of Arbuscular Mycorrhizal Fungi. Appl. Environ. Microbiol. 2004, 70, 6643-6649. [CrossRef] [PubMed]

53. Akiyama, K.; Matsuoka, H.; Hayashi, H. Isolation and identification of a phosphate deficiency-induced C-glycosylflavonoid that stimulates arbuscular mycorrhiza formation in melon roots. Mol. Plant Microbe Interact. 2002, 15, 334-340. [CrossRef]

54. Akiyama, K.; Matsuzaki, K.I.; Hayashi, H. Plant sesquiterpenes induce hyphal branching in arbuscular mycorrhizal fungi. Nature 2005, 435, 824-827. [CrossRef] [PubMed]

55. Ma, X.; Luo, W.; Li, J.; Wu, F. Arbuscular mycorrhizal fungi increase both concentrations and bioavilability of Zn in wheat (Triticum aestivum L) grain on Zn-spiked soils. Appl. Soil Ecol. 2019, 135, 91-97. [CrossRef]

56. Paneque, M.; María, J.; Rosa, D.; Aragón, C.; Kern, J.; Conte, P. Sewage sludge hydrochars: Properties and agronomic impact as related to different production conditions. Geophys. Res. Abstr. 2015, 17, 3-4.

57. Zhang, S.; Lehmann, A.; Zheng, W.; You, Z.; Rillig, M.C. Arbuscular mycorrhizal fungi increase grain yields: A meta-analysis. New Phytol. 2018, 222, 543-555. [CrossRef] [PubMed]

58. Zarei, M.; Abadi, V.A.J.M.; da Silva, J.A.T. Potential of arbuscular mycorrhizae and tall fescue in remediation of soils polluted with zinc. Chem. Ecol. 2020, 36, 122-137. [CrossRef]

59. Monnet, F.; Vaillant, N.; Hitmi, A.; Sallanon, H. Photosynthetic activity of Lolium perenne as a function of endophyte status and zinc nutrition. Funct. Plant Biol. 2005, 32, 131-139. [CrossRef]

60. Zinzala, V.N.; Narwade, A.V.; Karmakar, N.; Patel, P.B. Influence of Zinc Applications on Photosynthesis, Transpiration and Stomatal Conductance in Kharif Rice (Oryza sativa L.) Genotypes. Int. J. Curr. Microbiol. Appl. Sci. 2019, 8, 150-168. [CrossRef]

61. Liu, C.; Hu, C.; Tan, Q.; Sun, X.; Wu, S.; Zhao, X. Co-application of molybdenum and zinc increases grain yield and photosynthetic efficiency of wheat leaves. Plant Soil Environ. 2019, 65, 508-515. [CrossRef]

62. Vassilev, A.; Nikolova, A.; Koleva, L.; Lidon, F. Effects of excess Zn on growth and photosynthetic performance of young bean plants. J. Phytol. 2011, 3, 58-62.

63. Sagardoy, R.; Vázquez, S.; Florez-Sarasa, I.D.; Albacete, A.; Ribas-Carbó, M.; Flexas, J.; Abadía, J.; Morales, F. Stomatal and mesophyll conductances to $\{\mathrm{CO}\} 2$ are the main limitations to photosynthesis in sugar beet (Beta vulgaris) plants grown with excess zinc. New Phytol. 2010, 187, 145-158. [CrossRef]

64. Tobin, A.J. Carbonic anhydrase from parsley leaves. J. Biol. Chem. 1970, 245, 2656-3666. [CrossRef]

65. Ohki, K. Effect of Zinc Nutrition on Photosynthesis and Carbonic Anhydrase Activity in Cotton. Physiol. Plant. 1976, 38, 300-304. [CrossRef]

66. Reed, M.I.; Graham, D. Carbonic anhydrase in plants: Distribution, properties and possible physiological functions. Prog. Phytochem. 1980, 7, 47-94.

67. Nelson, E.B.; Cenedella, A.; Tolbert, N.E. Carbonic anhydrase in Chlamydomonas. Phytochemistry 1969, 8, 2305-2306. [CrossRef]

68. Hatch, M.D.; Slack, C.R. Photosynthetic CO2-Fixation Pathways. Annu. Rev. Plant Physiol. 1970, 21, 141-162. [CrossRef]

69. Sharma, P.N.; Tripathi, A.; Bisht, S.S. Zinc requirement for stomatal opening in cauliflower. Plant Physiol. 1995, 107, 751-756. [CrossRef]

70. Chen, Y.-Y.; Hu, C.-Y.; Xiao, J.-X. Effects of arbuscular mycorrhizal inoculation on the growth, zinc distribution and photosynthesis of two citrus cultivars grown in low-zinc soil. Trees 2014, 28, 1427-1436. [CrossRef]

71. Nguyen, T.D.; Cavagnaro, T.R.; Watts-Williams, S.J. The effects of soil phosphorus and zinc availability on plant responses to mycorrhizal fungi: A physiological and molecular assessment. Sci. Rep. 2019, 9, 1-13. [CrossRef] 